\title{
Percepční hodnocení vlastností pěveckého provedení koloraturní árie
}

\section{Perceptual Evaluation of Singing Performance of the Coloratura Aria}

\author{
Marek Frič / marek.fric@centrum.cz
}

Alexandra Berti / berti01@st.amu.cz

Jan Otčenášek / jan.otcenasek@hamu.cz

Musical Acoustic Research Center, Music and Dance Faculty, Academy Of Performing Arts in Prague, CZ

\begin{abstract}
The study presents the results of a controlled auditory evaluation of two parts of a W. A. Mozart Non mi dir aria from Don Giovanni. The aria was selected based on a higher technical difficulty of the role which includes both dramatic and difficult coloratura sections. The research has therefore focused on individually evaluating the recordings of the slower and coloratura excerpts of the aria (referred to as rondo and coloratura). Recordings of 17 performers (dated from 1907) were used in the listening tests. Twenty respondents participated in the evaluation (5 university singing pedagogues, 7 other pedagogues, 5 amateur singers and one student of sound production). The properties of extent of bright and dark components, voluminosity of voice and vibrato adequacy were assessed in the tests. Dramatic aspects of suitability of the voice were evaluated in the rondo excerpt and musical rendition, flexibility of the voice and vowel quality were evaluated in the coloratura part. Verbal descriptions of the recordings by the respondents were also collected. The results show a relatively low agreement of the professional groups on evaluations in the rondo section and a considerably higher agreement in the evaluation of coloratura. It was also possible to divide the respondents in two basic groups according to the relationships of the assessments: a group with preference in evaluating dark components and voluminosity (which were dominant in the slower part), and a group associating evaluated suitability of the voice with vibrato adequacy. Adequate vibrato was also found as significantly associated with flexibility of the voice in coloratura. The study also shows dark and bright components are not polar opposites of one perceptual dimension and their evaluation is context dependent.
\end{abstract}




\section{Keywords}

Singing, coloratura, perceptual evaluation

\section{Úvod}

Pro účely úvodní úvahy lze pěveckou interpretaci pojmout v analogii k instrumentálním výkonům: „tělo zpěváka lze přirovnat $k$ nástroji interpreta a hlas $k$ hudebnímu výsledku interakce interpreta a nástroje. "1

Pro pozorovatele pěveckého výkonu jsou tělo i hlas jedinými viditelnými nebo slyšitelnými prostředky, na základě nichž lze výkon interpreta vnímat a hodnotit. Za základní způsob hodnocení kvality a techniky hlasu lze pak považovat zejména poslech. Interpreti však k popisu zpěvu užívají více modalit percepčních vjemů. Ty obnášejí krom vlastností zvuku, gest těla a výrazu tváře i další modality, které nesouvisejí se sluchem, např́klad kinestetickou úroveň vnitřních hmatových představ týkající se způsobu tvorby hlasu. ${ }^{2}$ $\mathrm{V}$ důsledku toho se $\mathrm{k}$ popisu pěveckého výkonu interpreta vedle vlastností popisujících estetické či emoční hodnocení užívá i bohatý slovník vztahující se k fyziologickým i fyzikálním dějům, který je založen na vnímání hlasu a subjektivních představách a nemusí tak nutně odpovídat skutečným fyziologickým i fyzikálním pozorováním.

U poslechového hodnocení tak jsou hodnoceny intonační, dynamické a rytmické i obecné kvalitativní vlastnosti hlasu, které dohromady tvoří rozšířený koncept popisu kvality hlasu. ${ }^{3}$ Ten, oproti tradičně vymezené barvě zvuku, ${ }^{4}$ zahrnuje i suprasegmentální fonetické hledisko, tedy všechny vlastnosti, které odlišují série stejných řečových nebo zpívaných segmentů. „Nově neni , informace“ o kvalitě hlasu obsažena jenom v samotném akustickém signálu, nýbrž v kognitivnich reprezentacích posluchače, které mu umožñuji dát význam danému signálu podle jeho znalostí (zkušeností), jeho cíli a kontextu poslechu. " ${ }^{5} \mathrm{Z}$ tohoto pohledu pak slovní popis vlastností zpěvu zahrnuje kromě akustických vlastností (39\%) ${ }^{6}$ zejména hodnocení jakosti (technika, estetické zhodnocení - $21 \%$ ) a informace o hudebním provedení (17\%), tvorbě hlasu (16\%), ale i o hlasovém zdraví.

V předkládané studii jsou uvedeny výsledky výzkumu hodnocených vlastností zpěvu u dvou částí árie Donny Anny Non mi dir z opery W. A. Mozarta Don Giovanni, které se

1 KOKOTSAKI, Dimitra - DAVIDSON, W. Jane - COIMBRA, Daniela. Investigating the Assessment of Singers in a Music College Setting: The Students‘ Perspective, Research Studies in Music Education, 2001, roč. 16, č. 1, s. 30 .

2 KOKOTSAKI et al., op. cit., s. 15-16, 30-32.

3 Ang.: voice quality, GARNIER, Maeva - HENRICH, Nathalie - CASTELLENGO, Michele - SOTIROPOULO, David - DUBOIS, Daniele. Characterisation of Voice Quality in Western Lyrical Singing: from Teachers` Judgements to Acoustic Descriptions, Journal of Interdisciplinary Music Studies, 2008, roč. 1, č. 2, s. 65.

4 Barva zvuku (témbr) - souhrn vlastností zvuků, které odlišují nestejné zvuky stejné výšky, hlasitosti a délky (von HELMHOLTZ, Hermann. Die Lehre von den Tonempfindungen als physiologische Grundlage für die Theorie der Musik. Braunschweig: Vieweg, 1863).

5 GARNIER et al., op. cit., s. 66.

6 Procentuální výsledky dle GARNIER et al., op. cit., s. 69. 
obě vyznačují vyšší relativní pěveckou náročností, avšak jsou vzájemně odlišné. Pomalejší část je charakteristická širším, neseným zpěvem a část koloraturní je charakteristická požadavkem na příslušnou pohyblivost hlasu. Studie se zaměřila na odlišnosti v hodnocení u jednotlivých skupin respondentů, na jeho souvislosti s celkovou kvalitou pěveckého provedení a na vztahy mezi hodnocenými vlastnostmi u jednotlivých částí zkoumané árie (odlišnost obou částí umožní srovnání rozdílů vlastnosti kvalitního provedení koloratury s vlastnostmi pomalejší části). Vzhledem k tomu, že téma poslechového hodnocení zpěvního hlasu nepatří v české literatuře mezi běžné, studii otevírá širší komentovaný přehled dosavadního experimentálního výzkumu.

Pochopení způsobu hodnocení vlastností hlasu je prvním krokem takzvaného psycho-akustického výzkumu, jehož hlavním cílem je propojení poslechově hodnocených vlastností s objektivně měřitelnými akustickými parametry zvuku. Výsledky uveřejněné v této studii však nejsou omezeny pouze na tento kontext a mají též celou řadu mezioborových přesahů. Provedený výzkum se proto zaměřil na identifikování schopnosti shody jednotlivých hodnotitelů a určení strategií hodnocení.

Na základě těchto informací byly následně zkoumány též základní zákonitosti kvalitního pěveckého provedení. Zjištění uveřejněná v této studii jsou výsledkem zpracování výsledků poslechového hodnocení na vizuálně-analogových škálách ${ }^{7}$ a slovních dat a opírají se zejména o statistické metody. $\mathrm{Z}$ důvodů čtivosti a přizpůsobení textu předpokládané čtenářské obci jsou partie věnované použité statistice a přímý komentář k tabelovaným datům přesunuty do části apendix a ve vlastním textu je ponechán prostor především částem bližším klasické muzikologii a teorii interpretace.

\section{Hodnocení vlastností hlasu z vokologického pohledu}

Percepčních studií v oblasti hodnocení hlasu nalezneme v české literatuře jen poskrovnu. Většina se zabývá problematikou poruch hlasu ${ }^{8}$ a vychází z hodnocení vlastností porušené kvality dle Hirana ${ }^{9}:$ drsnost, dyšnost, slabost a napětí. Novější - komplexnější př́ístupy v popisu poruch hlasu pak vychází i z doporučení hlasových pedagogů a terapeutů, kde se kromě akustických projevů poruchy v podstatně větší míře dává dưraz na hodnocení ostatních - zejména tělesných vlastností (stoj, postoj, dech, vokální trakt, rezonance, artikulace aj.) a s nimi spojených dovedností. ${ }^{10}$ Byl publikován i jejich souhrnný rozbor

7 Škálování je způsob hodnocení, kdy se jednotlivým ukázkám určí př́íslušná číselná hodnota míry sledované vlastnosti (jako např. míra tmavých složek). Pokud je hodnocení umožněno zvolením hodnoty označením na úsečce (kde můžou být označeny míry jako malý, střední, veliký apod.), nazývá se vizuálně-analogová škála.

8 Např́klad viz: VOKŘÁL, Jan. Akustické parametry chraptivosti. Disertační práce. Praha: ČVUT v Praze, Fakulta elektrotechnická, 1998; FRIČ, Marek - KRASŃANOVÁ, Viera. Vztah mezi parametry hlasového pole a percepčním hodnocením poruchy hlasu u mužů, Otorinolaryng. a Foniat. /Prague/, 2014, roč. 63, č. 1, s. 16-28; VITÁSKOVÁ, Kateřina a kol. Výzkum poruch a odchylek komunikačni schopnosti a orofaciálního systému z logopedického hlediska. Olomouc: Univerzita Palackého v Olomouci, 2017. 206 s.

9 HIRANO, Minoru. Clinical Examination of Voice. 1. vyd. Vienna: Vienna Springer, 1981, s. 81-84.

10 SHEWELL, Christina. Voice Work: Art and Science in Changing Voices. 1. vyd. New Jersey: Wiley-Blackwell. s. 82-103. 
včetně doporučeného způsobu hodnocení, ${ }^{11}$ který se zaměřil spíše na diagnosticko-terapeutické hledisko.

Při hodnocení zpěvního hlasu v oblasti klasického zpěvu je však potřeba hodnotících vlastností výrazně odlišná, a proto je v řadě světových prací předmětem samostatných výzkumů.

Jeden z prvních pokusů o vytvoření standardního protokolu hodnocení představuje studie Wapnick a Ekholm, 1997, ${ }^{12}$ ve které byly na základě hodnocení Mozartovy árie $R i$ dente la calma (KV 152, 210a) pomocí tzv. faktorové analýzy identifikovány 3 faktory hodnocení: ${ }^{13}$ vnitřní kvalita, zahrnující vlastnosti: barvu/teplo, přiměřenost vibrata, rezonanci /zvonivost ${ }^{14}$ dynamický rozsah a intenzitu, faktor provedení zahrnující vlastnosti: flexibilita,

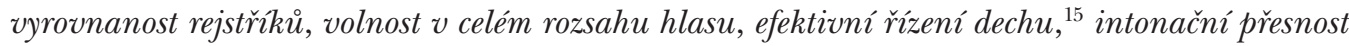
a legatová linka, poslední faktor byla samostatně dikce.

Navazující studie ${ }^{16}$ se na příkladu hodnocení Mozartovy árie Ch’io mi scordi di te (KV $505)$ zaměřila na podrobnější zkoumání vybraných čtyř vlastností a jejich propojení s akustickými vlastnostmi. Vlastnost barva/teplo byla představena jako vlastnost související s plností, okrouhlostí, tmavostí a bohatostiti a spojená s krytím, a naopak atributy tenký, bledý, světlý a ostrý (pisklavý) $)^{18}$ byly popsány jako spojené s nedostatkem barvy/tepla. Rezonance/zvonivost byla akusticky dána do významné souvislosti s celkovou hladinou akustického tlaku (SPL) a hladinou v oblasti pěveckého formantu. ${ }^{19} \mathrm{U}$ vokálů „a“ a „O“ byla zvonivost spojena i s vy̌šsí průměrnou pozicí vokalických formantů. ${ }^{20} \mathrm{U}$ přiměře-

11 FRIČ, Marek - OTČENÁŠEK, Zdeněk. Přehled metodických postupů subjektivního popisu vlastností hlasových projevů v oblasti poruch, patologie a terapie hlasu. Otorinolaryng. a Foniat. (Prague), 2010. roč. 59, č. 4, s. 214-24.

12 WAPNICK, Joel - EKHOLM, Elizabeth. Expert consensus in solo voice performance evaluation, J Voice, 1997, roč. 11, č. 4, s. 429-436.

13 Faktor hodnocení vzniká na základě statistické analýzy - faktorová analýza (FA). FA hledá pomocí korelace jednotlivých parametrů jednodušší vysvětlení celkové variability dat. Sloučí dohromady parametry (sledované vlastnosti), které spolu nejvíce souvisí, a vytvoří tak jednotlivé faktory. Zároveň platí, že jednotlivé faktory jsou na sobě nezávislé.

14 Ang.: color/warmth, appropriate vibrato, resonance/ring, viz WAPNICK, op. cit., s. 433.

15 Ang.: evenness of registration, freedom throughout vocal range, efficient breath management, viz ibid, s. 443.

16 EKHOLM, Elizabeth - PAPAGIANNIS, C. Georgios - CHAGNON, P. Francoise. Relating objective measurements to expert evaluation of voice quality in Western classical singing: critical perceptual parameters, J Voice, 1998, roč. 12, č. 2, s. 182-196.

17 Ang.: fullness, roundness, darkness and richness, viz EKHOLM et al., op. cit., s. 183.

18 Ang.: thin, white, light, reedy, viz ibid, s. 183.

19 Formant je spektrální oblast, kde je nahromaděna akustická energie na rozdíl od jejího okolí, středová frekvence určuje polohu formantu a souvisí s rezonanční frekvencí příslušné dutiny (vokálního traktu), resp. skupiny dutin. Čím je dutina větší, tím hlubší je poloha charakteristické frekvence. U klasicky pěvecky trénovaných mužů (a hlubších ženských hlasů) dochází následkem speciálního nastavení přechodu hrtanu do hltanu k přiblížení třetího až pátého formantu, čímž se vytvoří jeden velmi silný formant - nazývá se pěvecký formant (singer's formant). Ten je př́ičinou charakteristické barvy hlasu operních pěvců a zároveň způsobuje, že je pěvec dobře slyšitelný i za doprovodu orchestru. Více viz SUNDBERG, Johan. Articulatory interpretation of the „singing formant“, J Acoust Soc Am, 1974, roč. 55, č. 4, s. 838-844.

20 První dva formanty (s nejhlubšími středovými frekvencemi, typicky méně než $2400 \mathrm{~Hz}$ ) v českém jazyku dobře odlišují jednotlivé vokály. 
nosti vibrata hrála negativní složku jeho nepřítomnost v první $0,5 \mathrm{~s}$ od začátku tónu. $\mathrm{Na}$ základě frekvence a rozsahu frekvenční modulace se nedal stanovit jednoznačný trend priměrenosti vibrata, ale studie vyzdvihla jako významnou hranici $6 \mathrm{~Hz}$ a $5 \%$ změnu frekvence, kdy nižší frekvence a větší rozkmit vedou k významnému zhoršení hodnocení vibrata, podobně jako i př́lišné amplitudové vibrato.

Vlastnostem barvy hudebního zvuku a jejím slovním popisem se v ČR věnovaly studie kolektivu Zvukového studia HAMU (dnes Výzkumné centrum MARC HAMU). ${ }^{21}$ Popisují až 1964 slovních atributů popisujících barvu hudebních zvuků. Na základě sledování vztahů 25 nejvýznamnějších slovních atributů stanovili tř́rozměrný prostor percepce barvy hudebního zvuku popsatelný dimenzemi: 1) temný, tmavý - jasný, světlý; 2) drsný, hrubý - jemný; 3) plný, široký - úzký. První dimenze se u hudebníků nejčastěji pojí s popisem barvy zvuku, druhá dimenze se vztahuje jak ke kvalitě hry, tak k uměleckému provedení. Třetí popisuje barvu i kvalitu hry na hudební nástroj. Významným zjištěním je, že nejčastěji popisovaná vlastnost - ostrý - patří do roviny prvních dvou dimenzí a nachází se v kvadrantu jasných a drsných zvuků.

Další výzkum sólového operního zpěvu pak byl představen ve studii Oates a kol., 2006. ${ }^{22}$ Dle hodnocení 9 zkušených hlasových pedagogů a pěvců bylo vybráno 5 základních vlastností: přiměrenost vibrata, ${ }^{23}$ intonačni presnost, zvonivost, vyrovnanost kvality v celém rozsahu ${ }^{24}$ a napětí. Společně s celkovým hodnocením by uvedené vlastnosti měly jednoznačně a dostatečně popisovat všechny významné aspekty operního zpěvu. Další vlastnosti vyváženost rezonance ${ }^{25}$ a vedeni dech $u^{26}$ byly podrobněji diskutovány. Vedeni dechu bylo ze základního hodnocení zpěvu vyloučeno, protože bylo obtížně samostatně hodnotitelné jenom na základě poslechu, v zásadě výrazně souviselo s hodnocením vyrovnanosti hlasu v celém rozsahu a s vibratem. Podobně i vyváženost rezonance byla vyloučena ze základního hodnocení, protože výrazně korelovala s vibratem a vedením dechu, její definice nebyla jednoznačná a významně se překrývala se zvonivosti a vibratem.

Obsáhlá studie Garnier a kol., 2008, ${ }^{27}$ v rozšířeném konceptu kvality podrobněji rozebírá významný sémantický pár temný - jasný, kde jasný28 není jenom opositem temných zvuků, ale i okrouhlých. Primárně je jasný zvuk charakterizovaný přítomností energie

21 ŠTĚPÁNEK, Jan - MORAVEC, Ondřej. Barva hudebního zvuku a jeji slovni popis - Výsledky grantového projektu GAČR 202/02/1370. 1. vyd. Praha: Hudební fakulta Akademie múzických umění v Praze, 2005 , s. 47.

22 OATES, M. Jennifer - BAIN, Belinda - DAVIS, Pamela - CHAPMA, Janice - KENNY Dianna. Development of an auditory-perceptual rating instrument for the operatic singing voice, J Voice, 2006, roč. 20, č. 1, s. $71-81$.

23 Pravidelné a hladké zvlnění frekvence tónu, popis dle OATES et al., op. cit., s. 80.

24 Ang.: ring, brilliance of tone; evennes troughout the range - vysvětleno jako: schopnost volného zpěvu v celém výškovém a dynamickém rozsahu bez nevhodných změn v kvalitě hlasu - popis dle OATES et al., s. 80.

25 Ang.: resonance balance (chiaroscuro) - vhodné vyvážení tmavých a světlých složek hlasu - popis dle OATES et al., op. cit., s. 80 .

26 Ang.: breath management - efektivní řízení dýchání - popis dle ibid, s. 80.

27 GARNIER, Maeva - HENRICH, Nathalie - CASTELLENGO, Michele - SOTIROPOULO, David - DUBOIS, Daniele. Characterisation of Voice Quality in Western Lyrical Singing: from Teachers‘ Judgements to Acoustic Descriptions, Journal of Interdisciplinary Music Studies, 2008, roč. 1, č. 2, s. 62-91.

28 Ang.: brightness, fran.: brillant - GARNIER et al., op. cit., s. 69. 
v oblasti pěveckého formantu, přítomností barvy a efektivity, ale v druhém smyslu je negativně spojován se světtlým charakterem metalického zvuku blízkého k pronikavému. Podobně jsou vysvětlovány různé významy vlastnosti světly..$^{29} \mathrm{~V}$ pozitivním směru je podobná vlastnosti jasný, ale v negativním bezbarvý - bledý. Deskriptor tmavý se zase týká dvou různých pěveckých technik jednak s krytím a jednak s tvořením trubice (prodloužením vokálního traktu pomocí špulení rtů). Další hledisko použití škály světlý - tmavý je interpretováno ve smyslu předo-zadní pozice artikulace vokálů.

Navazující studie ${ }^{30}$ dále sumarizuje předešlé výsledky a dává je do užšího kontextu s akustickou analýzou. Studie rozlišuje základní hlediska popisu kvality hlasu: 1) percepci hlasového gesta nebo techniky, 2) percepci zvuku a 3) percepci proveden ${ }^{11}$ (interpretace). Třetí hledisko a čtvrté hledisko (nazváno oceněni libosti) ${ }^{32}$ nejsou ve studii podrobněji rozebírána. Hodnocení provedení a interpretace potřebuje samostatný navazující výzkum, kdežto hledisko libosti je ovlivněno zejména subjektivními (estetickými) kritérií a je velmi variabilní mezi hodnotiteli.

K uvedenému hledisku percepce hlasového gesta nebo techniky lze zařadit popisy fyziologických nebo fyzikálních dějů při tvorbě hlasu. Ty se však nemusí opírat o skutečnou fyziologickou nebo fyzikální realitu. Jsou pak popisovány subjektivní představy o uvedených dějích. Do této skupiny patří popis dechu, vibračni dynamika (dělící se na hlasové začátky/konce, hrtanové mechanismy, a melodickou linku) a vibrato (přítomnost, frekvence a rozsah, a jeho kontrolu v průběhu fráze). Lokalizace zdroje (umístnění) je popisováno ve směrech přední - zadní, v hlavě - v hrtanu, v krku - v nose. Dále sem patří vlastnosti jako dyšný, tlačený, otevřený, krytý, nebo způsob tvorby bližší řeči nebo zpěvu. Do hlediska percepční popis zvuku lze zařadit hodnocení zvuku na základě fonetických kritérií na segmentální a na suprasegmentální úrovni, hodnocení barvy (poloha hlasu, př́tomnost zvonivosti, vyváženost spektra, homogenita, tmavost - světlost). Hodnocení výšky a intenzity hlasu se opírá o hodnocení správnosti intonace, síly/slabosti hlasu a efektivity ve smyslu použitého úsilí vzhledem k vytvořené hlasitosti hlasu. Hlasový rozsah je dáván do vztahu dynamických možností v různých výškových polohách hlasu. ${ }^{33}$

Velká skupina studií se snaží najít objektivní prostředky pro hodnocení celkové kvality pěveckého výkonu. Např́ḱlad ve studii Cao a kol, 2008, ${ }^{34}$ autoři vychází z již popsaných percepčních protokolů. ${ }^{35} \mathrm{~V}$ jejich studii však pozměnili některé hodnocené vlastnosti. $\mathrm{K}$ intonačni presnosti přidali i rytmickou konzistenci, které jim vyšly dle hodnocení 5 poslu-

29 Ang.: light, fran.: clair - ibid, s. 69.

30 HENRICH, Nathalie - BEZARD, Pascal - EXPERT, Robert - GARNIER, Maeva - GUERIN, Christian PILLOT, Claire - QUATTROCCHI, Sophie. Towards a Common Terminology to Describe Voice Quality in Western Lyrical Singing: Contribution of a Multidisciplinary Research Group, Journal of Interdisciplinary Music Studies, 2008, roč. 2, vol. 1, 2, s. 75 .

31 Ang.: perception of vocal gesture or vocal technique, perception of sound, perception of performance.

32 Ang: pleasure judgment, HENRICH et al., op. cit., s. 75.

33 HENRICH et al., op. cit., s. 76-79.

34 CAO, Chuan - LI, Ming - LIU, Jian - YAN, Yonghong. An objective singing evaluation approach by relating acoustic measurements to perceptual ratings, In: 9th Annual Conference of the International Speech Communication Association, Brisbane: INTERSPEECH, 2008, s. 2058-2061.

35 WAPNICK et al., 1997; EKHOLM et al., 1998; OATES et al., 2006. 
chačů (profesionálních hudebníků) jako zásadní pro zpěv. Autoři studie naopak z protokolu vyloučili hodnocení vibrata, protože se dle nich v nahrávkách neodlišovalo. V studii byly sledovány i vlastnosti světlost, ${ }^{36}$ volnost hlasu v hlasovém (výškovém i dynamickém) rozsahu a čistota hlasu. ${ }^{37}$ Volnost hlasu v celém rozsahu hlasu jako jediná nepřispívala k celkové kvalitě provedení, což autoři vysvětlili tím, že v použitých - krátkých ukázkách nebylo možné dobře hodnotit uvedenou vlastnost. Další výsledky studie ukázaly významné souvislosti hodnocených vlastností s akustickými parametry ukázek.

Hodnocení zpěvního hlasu se věnovaly též předchozí studie autorského kolektivu této práce ${ }^{38} \mathrm{~V}$ těchto studiích byly zkoumány základní technické vlastnosti zpěvu. Dle párového porovnání zpěvu lidové písně skupiny 18 mužů (2 operní pěvci, 5 herců a 11 studentů herectví) a hodnocení „pěveckého protokolu“39 bylo ukázáno, že operní pěvci se vyznačují výrazně odlišnou technikou zpěvu, která se percepčně projevuje zejména tmavostí. Percepční prostor zpěvu profesionálních herců a studentů herectví prokázal tři základní, na sebe kolmé dimenze ${ }^{40}$ tmavost, šiřku a drsnost v hluboké poloze hlasu. Celková kvalita pak ležela v rovině tmavý a široký, vlastnosti pěveckého protokolu v zásadě korelovaly s dimenzí tmavosti. Vyšší poloha zpěvu již nebyla jednoduše vysvětlitelná. V prostoru všech 18 subjektů jenom druhá dimenze korelovala s drsností a u herců a studentů v zásadě jenom první dimenze obecně korelovala s vlastnostmi pěveckého protokolu.

V další skupině studií ${ }^{41}$ byly porovnávány akustické i percepční vlastnosti trénované skupiny zpěvaček (klasický zpěv na úrovni konzervatoře) a netrénované skupiny studentek hudební výchovy. Kromě zásadních rozdílů při měření hlasového pole, resp. výškových a dynamických schopností hlasu, se prokázaly odlišnosti zejména v hodnocení tmavosti a rezonance hlasu u zpěvu lidové písně. Zpěvačky měly hlas rezonovanějši a v hlubší tónině i středně tmavý. Př́liš tmavé hlasy nezpěvaček však nebyly schopny zazpívat lidovou píseň ve vyšší tónině. Při habituálním čtení nebyly trénované zpěvačky odlišitelné od nezpěvaček. Z uvedeného zjištění byla tmavost rozdělena na typ tmavosti, který odlišuje klasické zpěvačky od netrénovaných studentek, a typ výrazného „zatmavení“ (až zapadnutí hlasu), který prezentuje spíše výrazně omezující - nevhodnou techniku zpěvu. Na druhé straně, ve studii Kulanová a Frič, $2012,{ }^{42}$ se dle percepčního protokolu ukázala

36 Ang.: timbre brightness (brilantnost tónu, pocit jasu, zvonivost a teplo) - CAO et al., op. cit., s. 2059.

37 Ang.: vocal clarity (pocit vibrací hlasu spojených s tvorbou kvalitního hlasu) - ibid, s. 2059.

38 FRIČ, Marek - OTČENÁŠEK, Zdeněk - KADLECOVÁ, Klára. Poslechové hodnocení vlastností zpěvu předběžná studie. In: Proceedings of the 6th International Symposium: Material - Acoustics - Place, 2011. Technical University in Zvolen, s. 83-93.

39 OATES et al., op. cit., s. 80-81.

40 Percepční dimenze - podobně jako faktory hodnocení, ale vzniknou na základě statistické analýzy hodnocení vzdáleností mezi jednotlivými stimuly pomocí metody multidimenzionálního škálování (MDS). Dimenze jsou navzájem kolmé osy vzniklého percepčního prostoru, podobně jako u 3D prostoru, ve kterém žijeme. MDS dimenze ale zobecňují konstrukt rozložení hodnocených stimulů na základě jejich podobnosti/nepodobnosti, a tedy popisují zásadní vlastnosti, které jsou navzájem nezávislé.

41 FRIČ, Marek - KADLECOVÁ, A. Klára. Porovnání vlastností a parametrů hlasu pěvecky trénovaných a netrénovaných žen. Akustické listy, 2012. roč. 18, č. 2-3, s. 5-24; FRIČ, Marek. Hodnocení rezonance hlasu žen, In: Nové trendy akustického spektra - vedecký recenzovaný zbornik, Zvolen: Material - Acoustics - Place, 2013, s. 73-88.

42 KULANOVÁ, Angelika - FRIČ, Marek. Komparácia náčuvových a počítačových akustických hodnotení 
jako jediná vlastnost, která odlišila experimentální skupinu studentů - podrobující se pěveckému tréninku - od kontrolní skupiny, a to zvýšená míra světlosti.

$\mathrm{V}$ poslední studii autorského kolektivu ${ }^{43}$ byla sledována schopnost percepčně ohodnotit typ hlasu z krátkých ukázek (recitativ/koloratura) z árie Una voce poco fa z opery Lazebník sevillský od G. Rossiniho. V práci byly kromě hlasového typu hodnoceny i vlastnosti tmavý-svètlý, míra rezonance, poloha vokáliu (předo-zadní), pohyblivost, př́ijemnost vibrata a celkový estetický dojem. Studie prokázala schopnost určit hlasový typ (mezzosoprán/soprán) zkušenými hlasovými pedagogy a pěvci, kdežto hodnocení skupinou hudebníků a amatérských zpěváků se do značné míry odlišovalo od životopisních údajů interpretek. Studie prokázala, že hodnocení hlasového typu souvisí s hodnocením světlosti-tmavosti a polohou vokálů. Míra rezonance byla obecně mezi skupinami hodnotitelů hodnocena nejméně konzistentně. Tento jev byl vysvětlen i na základě studie, ${ }^{44}$ kde byl prokázán významný rozdíl mezi strategiemi hodnocení míry rezonance mezi hlasovými odborníky pocházejícími z různých odvětví. Skupina pěvecky trénovaných subjektů výrazně častěji spojovala vyšší míru rezonance se zesílením pásma první harmonické složky, kdežto skupina hlasových terapeutů v zásadě hodnotila rezonanci jako zesílení v pásmu pěveckého formantu $(2-4 \mathrm{kHz})$. K závěru, že rezonance/zvonivost je mnohodimenzionální vlastnost, došla i studie Oates et al., $2006,{ }^{45}$ kde uvedená škála byla nahrazena separátním hodnocením vyváženosti rezonance a samostatným hodnocením zvonivosti. Hlasová rezonance je jev, který popisuje různé fenomény hlasu, a tím pádem je závislá i na jejich citlivosti u jednotlivých hodnotitelů. Další významné zjištění předchozí studie ${ }^{46}$ ukazuje rozdíl ve strategii hodnocení estetického dojmu mezi pedagogy, kteříji nejvíce spojovali s hodnocením rezonance, kdežto hudebníci ji hodnotili nezávisle. Ti naopak spojovali hodnocení rezonance s vibratem. Pedagogové u koloraturní části spojovali vhodné vibrato s lepší flexibilitou hlasu.

\section{Materiál a metody}

\section{Motivace pro výběr zvukových ukázek}

Jako podklad pro náš výzkum jsme zvolili výňatek z opery Wolfganga Amadea Mozarta (1756-1791) Don Giovanni (původní název Il dissoluto punito, ossia Il Don Giovanni; Potrestaný prostopášník aneb Don Giovanni, KV 527) zkomponované na libreto Lorenza Da Ponteho (1749-1834).

speváckych vlastností hlasu. DISPUTATIONES SCIENTIFICAE UNIVERSITATIS CATHOLICAE IN RUŽOMBEROK, 2012, roč. 12, č. 2, s. 79-98.

43 FRIČ, Marek - PAVLECHOVÁ, Angelika. Listening evaluation and classification of female singing voice categories, Logopedics Phoniatrics Vocology, (v tisku).

44 FRIČ, Marek. Strategie poslechového hodnocení rezonance hlasu. In: Nové trendy akustického spektra - vedecký recenzovaný zbornik, Zvolen: Material - Acoustics - Place, 2014, s. 73-80.

45 OATES et al., op. cit., s. 80-81.

46 FRIČ - PAVLECHOVÁ, op. cit. 
Rozličné nahrávky dvouaktové opery skýtají bohatý materiál pro percepční a akustický výzkum v podobě různorodé interpretace role Donny Anny (u některých starších pouze árií) na snímcích pořízených v poměrně širokém časovém horizontu (1906-2011).

Pro naše účely jsme vybrali Recitativo e Rondo z druhého jednání opery. Donna Anna, komturova dcera a snoubenka Dona Ottavia, se zde zdráhá vyslyšet prosbu o uzavření sňatku s Donnem Ottaviem, nebot žije stále ve vzpomínkách na hrůzný zážitek vraždy svého otce. Konkrétně jsme se soustředili na takt 20. až 27. v tempu Larghetto - Non mi dir, bell‘ idol mio, che son io crudel con te, kde už melodie v klarinetu, v dynamice sotto voce, předjímá charakter širokého, neseného zpěvu. Tato část je v článku zkráceně označována jako rondo.

Druhá ukázka představuje koloraturu „sentira pieta di me“, od taktu 81. po takt 93. v tempu Allegretto moderato.

Tyto dva kusy, podle našeho názoru, v mnohém charakterizují obtížnost pěveckého partu z hlediska pohyblivosti a zároveň ještě dostatečně kontrastují, což bylo pro účely testu žádoucí. Jelikož se jedná o zvukový záznam jediného čísla, zvyšuje se pravděpodobnost zachování jednoty nastavení nahrávací techniky a času, ve kterém byla patrně nahrávka uskutečněna.

Z hlediska interpretačního považujeme roli Donny Anny za extrémně exponovanou dramatickou partii, která v sobě zahrnuje nutnost sloučení brilantních koloraturních pasáží současně s velkým dynamickým rozpětím a šiří hlasového nasazení. Vezmeme-li v úvahu zachování dramatičnosti pěveckého partu, nutný dynamický výkon hlasu v konkurenci orchestru a zároveň lehkost a brilanci koloratur s ohledem na velikost role a hlasový rozsah, je zřejmé, že si partie Donny Anny žádá obsazení všestranně hlasově, technicky a dramaticky vybavenou interpretkou.

Pro účely otázek a škálování hodnocení v poslechovém hodnocení jsme vycházeli též z Mozartových požadavků plynoucích z kompozice jeho Solfeggií KV 393 editovaných dirigentem Hansem Swarowskym. Editor v předmluvě prezentuje toto dílo jako dokonalý důkaz pro zvláštní nároky, které Mozart klade na hlas. Prvních šest taktů prvního kusu považuje za motto pěveckého umění. Podle jeho názoru vyžadují totální hlasové rozpětí při stále stejné intenzitě nasazeného tónu, jistou oporu, dlouhý a rovnoměrný výdech, klidné, plné messa di voce, vyrovnanost poloh bez zlomů a výraznou ohebnost hlasu. Solfeggi tak obsahují vše, co dokonalá Konstanze, hraběnka, Anna, Elvira, Fiordiligi, Dorabella a Královna noci musejí umět. ${ }^{47}$

V druhém testu námi použitá koloratura „sentira pieta di me“, která je tak charakteristická pro Mozartův styl, vychází z požadavků na koloraturní zpěv obecně. Z pěveckého partu Donny Anny je patrné, že důraz je kladen na pohyblivost, virtuozitu, zdobnost, brilanci passagií, rulád a běhů spojených s velkými intervalovými skoky, na lehkost a rychlost provedení ruku v ruce s dokonalým ovládáním hlasového aparátu. V tomto smyslu part Donny Anny jasně nese stopy odkazu kompozičního a pedagogického působení neapolských mistrů, pod jejichž vlivem doznal koloraturní zpěv v 18. století největšího rozkvětu. ${ }^{48}$

47 SWAROWSKY, Hans. Vorbemerkung zu W. A. Mozarts Solfeggi (K. V: 393); Wien 1956.

48 Zpracováno dle popisů uvedených v: Conversations-Lexikon oder kurzgefaßtes Handwörterbuch (1809, Bd. 1, S. 281); Damen Conversations Lexikon (1834-1838, Bd. 2, S. 454); Herders Conversations-Lexikon (1854-1857, Bd. 2, S. 167); Meyers Großes Konversations-Lexikon (1905-1909, Bd. 11, S. 304); Seeger, Horst, 
Z pozice našeho výzkumu je velmi interesantní zpěvná melodičnost, it. canorita (z lat. canorus), spojovaná s koloraturním zpěvem, pro kterou jsou charakteristické ,forza $e$ chiarezza di voce" - síla a světlost, čistota, jasnost a zřetelnost, průzračnost hlasu. Těmto všem fenoménům se věnují i slovní popisy našich respondentů, at’ se jedná o profesionály, či pěvecké amatéry.

\section{Použité nahrávky a sestavení hodnotících škál}

Výzkumu byly podrobeny zvukové záznamy 17 různých interpretek. Jména interpretek včetně popisů užitých zvukových nahrávek jsou uvedena v tabulce $1 .^{49}$

\begin{tabular}{|r|l|l|c|l||}
\hline \hline ID & Interpretka & Zdroj & Rok nahr. & Orchestr, dirigent \\
\hline \hline 1 & Anna Netrebko (*1971) & YT & 2011 & Teatro alla Scala, Daniel Barenboim \\
\hline 2 & Anna Tomowa-Sintow (*1941) & YT & 1987 & Wiener Philharmoniker, Herbert von Karajan \\
\hline 3 & Rose Bampton (1907-2007) & NX, CD & 1942 & Live Recording: New York, Bruno Walter \\
\hline 4 & Barbara Frittoli (*1967) & YT & 2000 & $\begin{array}{l}\text { Scottish Chamber Orchestra, Charles } \\
\text { Mackerras }\end{array}$ \\
\hline 5 & Diana Damrau (*1971) & YT/NX & 2008 & Le Cercle de L'Harmonie, Jérémie Rhorer \\
\hline 6 & Edita Gruberová (*1946) & YT/NX & 2005 & Wiener Staatsoper, Zubin Mehta \\
\hline 7 & $\begin{array}{l}\text { Felcie Hüni-Mihacsek } \\
(1891-1976)\end{array}$ & CD & 1927 & není uvedeno \\
\hline 8 & Joan Sutherland (1926-2010) & YT/NX & 1959 & Philharmonia Orchestra, Carlo Maria Giulini \\
\hline 9 & Lilli Lehmann (1848-1929) & NX, CD & 1907 & není uvedeno \\
\hline 10 & Lena Nordin (*1956) & NX & 1991 & $\begin{array}{l}\text { Hannover Radio Philharmonic Orchestra, } \\
\text { Cord Garben }\end{array}$ \\
\hline 11 & Lisa Della Casa (1919-2012) & YT & 1957 & Wiener Philharmoniker, Heinrich Hollreiser \\
\hline 12 & Lucia Popp (1939-1993) & NX & vyd. 2008 & Munich Radio Orchestra, Leonard Slatkin \\
\hline 13 & Maria Callas (1923-1977) & CD & 1953 & $\begin{array}{l}\text { Orchestra del Maggio Musicale Fiorentino, } \\
\text { Tullio Serafin }\end{array}$ \\
\hline 14 & Milada Šubrtová (1924-2011) & NX & vyd. 1999 & $\begin{array}{l}\text { Prague National Theatre Orchestra, } \\
\text { Zdeněk Chalabala }\end{array}$ \\
\hline 15 & Suzanne Danco (1911-2000) & CD & 1959 & Wiener Philharmoniker, Josef Krips \\
\hline X & Helen Donath (*1940) & NX & vyd. 2007 & $\begin{array}{l}\text { English Chamber Orchestra, Daniel Baren- } \\
\text { boim }\end{array}$ \\
\hline Y & Gundula Janowitz (*1937) & NX & 1967 & Wiener Staatsoper, Josef Krips \\
\hline
\end{tabular}

Tab. 1 Charakterizace stimulových nahrávek, informace o nahrávkách a interpretkách. Seznam vybraných interpretek a označení jejich stimulových nahrávek. Zdroje: YT - youtube. com, NX - NAXOS Music Library, CD - soukromé CD nosiče. Rok nahrávky: pozn. vyd. je znám jenom rok vydání CD.

Opern Lexikon. Berlin 1989; Die Musik in Geschichte und Gegenwart. Kassel, 1989.

49 Protože nahrávky z NAXOS Music Library a Youtube neměly jednotný formát záznamu, byly převzorkovány na jednotný formát $44,1 \mathrm{kHz} / 16$ bit. Podněty byly též dále srovnány na stejnou, průměrnou hladinu akustického tlaku (SPL). 
Z uvedených nahrávek byly vytvořeny dva poslechové testy. Poslechové hodnocení bylo provedeno ve webové počítačové aplikaci PsychotestEditor, která umožňuje u připraveného testu provádět vzdálené hodnocení přes web..$^{50}$

Výše uvedený rozpor významu dimenze světlý-tmavý s ohledem na pěvecký trénink, jakož i rozbor uvedený v Garnier et al, 2007, ${ }^{51}$ ukazuje na nejednotnost výkladu těchto vlastností, které jsou často vyhodnocovány v protichůdných smyslech k celkové kvalitě hlasu. Z tohoto do̊vodu v tomto výzkumu nebyly světlé a tmavé složky hodnoceny na bipolární škále (jako jednotná dimenze), ale byly hodnoceny na oddělených a nezávisle prezentovaných škálách. V předkládané studii jsme se vzhledem k nejasnosti přesného významu dle výše uvedeného rozboru též rozhodli nehodnotit vlastnost rezonance hlasu (i přesto, že v českém prostředí patří k nejčastěji užívaným termínům). Místo toho byly hodnoceny související vlastnosti jako kvalita provedení a vibrato.

V prvním testu byly hodnoceny zvukové úryvky části rondo, ve druhém pak úryvky části koloratura. Hodnotitelé měli za úkol ve vyhrazené části (poznámky) spontánně popsat nejvýznamnější vlastnosti hlasu. V prvním testu bylo posléze hodnoceno pět vlastností na pěti škálách: míra světlých složek hlasu, míra tmavých složek hlasu, vibrato, mohutnost hlasu, vhodnost hlasu z hlediska dramatického ztvárnění, ve druhém celkem sedm vlastností na škálách, místo vhodnosti hlasu bylo hodnoceno hudebni provedeni, dále byly přidány škály pohyblivost hlasu a kvalita vokalizace. Ke kvalitě vokalizace bylo možné připsat specifické poznámky. Podrobnější vysvětlivky k parametrům hodnoceným na vizuálně-analogových škálách jsou uvedeny v tabulce 2 tak, jak byly v testech prezentovány na úvodní obrazovce jako instrukce k provedení testu.

\begin{tabular}{|c|c|c|c|}
\hline Typ testu & Zkratka & Označení v testu & Popis \\
\hline $\mathrm{R} / \mathrm{K}$ & Poznámky & $\begin{array}{l}\text { Popis nahrávky - } \\
\text { obecný dojem }\end{array}$ & $\begin{array}{l}\text { Do poznámky dopište (aspoň tři) nejvýraznější vlastnosti, } \\
\text { nebo postřehy, které Vás napadnou. }\end{array}$ \\
\hline $\mathrm{R} / \mathrm{K}$ & Světlé & $\begin{array}{l}\text { Přítomnost svět- } \\
\text { lých složek hlasu }\end{array}$ & $\begin{array}{l}\text { Určete poměr zastoupení světlých složek hlasu (lesk, špič- } \\
\text { ka). Posunem posuvníku na levou stranu škály hodnotte } \\
\text { "málo" světlých složek, na pravé straně "hodně" světlých } \\
\text { složek. }\end{array}$ \\
\hline $\mathrm{R} / \mathrm{K}$ & Tmavé & $\begin{array}{l}\text { Přítomnost tma- } \\
\text { vých složek hlasu }\end{array}$ & $\begin{array}{l}\text { Určete poměr zastoupení tmavých složek hlasu. Posu- } \\
\text { nem posuvníku na levou stranu škály hodnotte "málo" } \\
\text { tmavých složek, posunem na pravou stranu - "hodně" } \\
\text { tmavých složek. }\end{array}$ \\
\hline $\mathrm{R} / \mathrm{K}$ & $\begin{array}{l}\text { Přiměře- } \\
\text { nost vib- } \\
\text { rata }\end{array}$ & Vibrato & $\begin{array}{l}\text { Na vizuální škále určete adekvátnost použitého vibrata. } \\
\text { Posunem posuvníku na levou stranu škály hodnot'te vib- } \\
\text { rato jako neadekvátní, na pravou stranu jako adekvátní }\end{array}$ \\
\hline $\mathrm{R} / \mathrm{K}$ & Mohutnost & Mohutnost hlasu & $\begin{array}{l}\text { Určete, jakou míru mohutnosti má hlas. Posunem posuv- } \\
\text { níku na levou stranu škály hodnotte málo mohutné hlasy, } \\
\text { na pravou stranu velmi mohutné hlasy. }\end{array}$ \\
\hline
\end{tabular}

50 KULHÁNEK, Tomáš - FRIČ, Marek - OTČENÁŠEK, Jan. Software pro tvorbu percepčnich testů na webovém rozhrani - software; MARC-Technologický list č́s. 82/16, Praha: MARC HAMU, 2016.

51 GARNIER et al., op cit., s. 71. 


\begin{tabular}{|c|c|c|c|}
\hline Typ testu & Zkratka & Označení v testu & Popis \\
\hline$R$ & $\begin{array}{l}\text { Vhodnost } \\
\text { hlasu }\end{array}$ & $\begin{array}{l}\text { Vhodnost hlasu } \\
\text { z hlediska drama- } \\
\text { tického ztvárnění }\end{array}$ & $\begin{array}{l}\text { Na vizuální škále určete, jestli a do jaké míry je hlas vhod- } \\
\text { ný pro daný repertoár. Posunem posuvníku na levou stra- } \\
\text { nu škály hodnot'te jako neuspokojující, na pravou stranu } \\
\text { jako vysoce uspokojující. }\end{array}$ \\
\hline K & Provedení & $\begin{array}{l}\text { Hudební prove- } \\
\text { dení }\end{array}$ & $\begin{array}{l}\text { Určete, jestli a do jaké míry je hlas vhodný pro daný reper- } \\
\text { toár. Posunem posuvníku na levou stranu škály hodnot'te } \\
\text { jako průměrný, na pravou stranu jako vynikající. }\end{array}$ \\
\hline K & Pohyblivost & Pohyblivost hlasu & $\begin{array}{l}\text { Určete, jak je hlas pohyblivý. Posunem posuvníku na le- } \\
\text { vou stranu škály hodnotte málo pohyblivé hlasy, na pra- } \\
\text { vou stranu dobře pohyblivé hlasy. }\end{array}$ \\
\hline K & Vokalizace & Kvalita vokalizace & $\begin{array}{l}\text { Určete, jak kvalitně je dodržená výslovnost vokálu "a" } \\
\text { ve slově "sentira", respektive jak často inklinuje k jinému } \\
\text { vokálu. Vlevo hodnot'te správné dodržení vokálu „a", vpra- } \\
\text { vo často se měnící vokál, nebo nesprávný vokál "a". }\end{array}$ \\
\hline K & $\begin{array}{l}\text { Pozn. } \\
\text { k vokálu }\end{array}$ & Pozn. k vokálu & $\begin{array}{l}\text { Pokud "a" inklinuje k jinému vokálu, napište pak do spe- } \\
\text { ciálního odpovědního pole, ke kterému, prípadně jiné po- } \\
\text { známky týkající se kvality vokalizace. }\end{array}$ \\
\hline
\end{tabular}

Tab. 2 Popis hodnocených vlastností v testech

Před začátkem testu měl respondent za úkol na základě poslechu ukázek s nejmenším a největším rozptylem hladiny akustického tlaku nastavit úroveň zesílení zvuku ve sluchátkách, tak aby mu byl poslech př́ijemný a úroveň hlasitosti byla vhodná pro hodnocení daného typu stimulu. Stimuly byly respondentům v testech předkládány v náhodném pořadí, stimuly bylo dovoleno přehrávat opakovaně. Na konci testu měli respondenti možnost test slovně zhodnotit.

\section{Respondenti - hodnotitelé}

Z celkového počtu 24 posluchačů vyplnilo obě části poslechového testu 20 respondentů, jejichž výsledky byly použity k další analýze. Délka pedagogické, pěvecké a amatérské praxe, trvání jednotlivých testů jsou u každého hodnotitele uvedeny v tabulce 3 (uvedené v apendixu). Na základě těchto vlastností byli hodnotitelé rozděleni do skupin: profesionální zpěváci, vysokoškolští pedagogové (pedagogická praxe: $15 \pm 15$ roků, pěvecká praxe: $37 \pm 9$ roků), pedagogové jiných uměleckých škol (pedagogická praxe: $18 \pm 13$ roků, pěvecká praxe: $20 \pm 14$ roků a amatérští zpěváci: $13 \pm 8$ roků). Jeden hodnotitel byl bez pěvecké zkušenosti. Vypracování každého testu trvalo v průměru mírně přes 60 minut. Podrobnosti týkající se zpracování dat jsou pak uvedeny v apendixu studie.

\section{Popis výsledků}

Pro vyšší přehlednost jsou v této části výsledky zhodnoceny pouze slovně. Podrobnější analytický popis s př́slušnými tabulkami je uveden v apendixu. 


\section{Rozbor hodnocení jednotlivých hodnotitelů - faktorová analýza}

Výsledky faktorové analýzy jednotlivých respondentů ukazují jednotlivé strategie souvisejícího hodnocení na užitých škálách, takže vlastnosti, které patří do stejného faktoru hodnocení, spolu nejvíce souvisí a způsob jejich hodnocení byl danými respondenty prováděn velmi podobně.

$\mathrm{V}$ poslechovém testu rondo patřilo hodnocení míry tmavých složek, mohutnost a vhodnost hlasu nejčastěji do prvního - nejvýznamnějšího faktoru. Světlé složky a priměřnost vibrata byly nejčastěji zastoupeny v třetím faktoru.

Pokud se podíváme na dvojice vlastností, nejčastěji patřily do stejného faktoru míra tmavých složek a mohutnost (u 13 hodnotitelů z 20), přměřnost vibrata a vhodnost hlasu (11 z 20) a míra světlých a tmavých složek (10 z 20 hodnotitelů).

Při hodnocení koloratury se strategie hodnocení změnila. Míra světlých složek, přiměrenost vibrata, celkové provedeni a pohyblivost patřily nejčastěji do prvního faktoru hodnocení. $\mathrm{V}$ druhém faktoru byly nejčastěji hodnoceny míra tmavých složek a mohutnost, ve třetím faktoru vokálni nepresnost.

Do stejného faktoru nejčastěji spadaly dvojice: přiměrenost vibrata a celkové provedeni, celkové provedeni a pohyblivost, tmavé složky a mohutnost, pohyblivost a světlé složky, a nakonec světlé a tmavé složky.

Podobné dvojice vlastností také nejčastěji tvořily první - nejvýznamnější faktor. Význam četností v tomto faktoru se zvýšil u dvojic: celkové provedeni a světlé složky a pohyblivost s přměrenosti vibrata, četnost dvojice světlé a tmavé složky klesla na nevýznamnou úroveň. Tmavé složky a mohutnost byly nejčastější dvojicí tvořící druhý faktor.

\section{Shoda hodnotitelů}

Všichni respondenti dohromady se při hodnocení ronda nejlépe shodli na hodnocení vlastností priměrenost vibrata a přitomnost tmavých složek a měli také dobrou shodu u hodnocení vlastností světlé složky a vhodnosti hlasu. Uvnitř jednotlivě profesně vymezených skupin sice panovala relativně nízká shoda, ta ovšem byla lepší při rozdělení hodnotitelů do kombinovaných skupin nebo do skupin vymezených na základě faktorové analýzy. Takto vymezená spojená skupina vysokoškolských pedagogů, profesionálních a amatérských zpěváků vykazovala shodu zejména u hodnocení vlastností světlých složek a spojená skupina profesionálních a amatérských zpěváků (společně s dirigenty) vykazovala shodu $\mathrm{u}$ hodnocení vlastností priměrenost vibrata a vhodnost hlasu.

Při hodnocení části koloratura byla shoda všech hodnotitelů i jednotlivých profesních skupin vyšší než u ronda. Celkově lepší shoda, než u všech 20 hodnotitelů, byla ve skupině vysokoškolských pedagogů, profesionálních zpěváků a dirigentů u vlastnosti světlé složky, u skupiny profesionálních a amatérských zpěváků a dirigentů u vlastnosti přiměrenost vibrata, a u skupiny vysokoškolských pedagogů, profesionálních zpěváků a amatérů u vlastnosti tmavé složky a vokálni nepresnost. 


\section{Souvislosti hodnocených vlastností}

U ronda vzájemně souviselo (na základě korelace) hodnocení všech vlastností, kromě dvojic přiměrenost vibrata a tmavé složky. U koloratury je vlastností bez vzájemné korelace více, než v části rondo, zejména hodnocení vokálni nepřesnosti. Nízké korelace má též priměrenost vibrata se zastoupením tmauých složek, tmavé složky s celkovým provedením či přiměrenost vibrata s mohutností.

Pokud se podíváme na souvislosti hodnocení podobných vlastností mezi typy ukázek (rondo vs. koloratura), společně nesouviselo hodnocení přiměrenosti vibrata ani provedeni $\mathrm{s}$ vhodnosti hlasu, tedy hodnotitelé hodnotili stejné interpretky v různých částech árie v daných vlastnostech různě. Ve skupině prof. zpěváků, dirigentů a amatérů nesouvisle se žádnou vlastností vokálni nepresnost ani přiměrenosti vibrata. Protichůdné hodnocení (zápornou korelaci) pak celkově vykazují hodnocení tmavých a světlých složek. Mezi nejvýznamnější zjištěné souvislosti patří hodnocení priměrenosti vibrata $\mathrm{v}$ rondu s hodnocením světlých složek v koloratuře a protichůdný vztah mezi světlými složkami v rondu a mohutností v koloratuře a též souvislost mohutnosti a tmavých složek, vhodnosti hlasu se světlými složkami a protichůdně s tmavými.

Hodnocení světlých složek v rondu přímo souviselo, i když korelačně velmi slabě, s hodnocením přiměrenosti vibrata, celkovým provedenim a pohyblivosti v koloratuře. Protichůdný vztah pak existuje mezi hodnocením přiměrenosti vibrata v rondu a mohutností v koloratuře, a též mezi hodnocením mohutnosti v rondu a pohyblivosti v koloratuře.

Faktorová analýza výsledných hodnocení všech hodnotitelů a skupin s nejlepší shodou potvrdila výše popsané výsledky. Nejvýznamnější faktor u těchto skupin v rondu vysvětloval většinu variability dat a byl sycen vlastnostmi tmavé složky a mohutnost. Druhý faktor byl sycen vlastnostmi přměřenost vibrata a vhodnosti hlasu, a třetí faktor byl sycen světlými složkami. U koloratury bylo stanoveno vhodné užití třech faktorů ${ }^{52}$ u skupiny všech hodnotitelů a čtyř faktorů u skupin s nejlepší shodou. To znamená, že skupiny s nejlepší shodou rozlišovaly víc významných oblastí hodnocení. V obou případech druhý faktor obsahoval světlé a tmavé složky a mohutnost, a třetí faktor obsahoval vokálni nepresnost. První faktor, který v obou případech obsahoval vlastnosti pohyblivost a provedení, ve skupině všech hodnotitelů obsahoval i vlastnost přiměrenost vibrata, která se v hodnocení nejshodnější skupiny profesionálních zpěváků, dirigentů a amatérů přesunula do samostatného faktoru.

\section{Vlastnosti slovního popisu}

$\mathrm{K}$ analýze volného slovního popisu vlastností v textových polích byla použita metoda korpusové analýzy (blíže viz apendix), kterou byla zjištována četnost popisovaných vlast-

52 Na základě grafu vlastních hodnot. 
ností (reprezentovaných užitými podstatnými jmény) a jejich přívlastků (reprezentovaných př́ídavnými jmény) $)^{53}$.

Z celkových četností použití jednotlivých vlastností vyplývá, že v koloraturní části byly oproti části rondo podstatně častěji popisovány dominantní vlastnosti koloratura, výška hlasu, tón, zvuk a tempo. V části rondo převládal popis zaměřený na dech, barvu, výslovnost, glissando, frázováni, vibrato a obecně hlas. Celkově nejčetnější vlastností u obou částí árie bylo vibrato, druhou a třetí nejčetnější vlastností byly tón a koloratura. Celkem bylo v koloraturní části užito 462 atributů, v části rondo 480.

Z četností použití př́ílastků v koloraturní části oproti části rondo jednoznačně převládají pohyblivost, presnost, tě̌̌kost, lehkost, těžkopádnost. V části rondo byly s větší převahou uváděny přívlastky světlost, dramatičnost, jasnost, měkkost, mohutnost a kulatost. Nejčastěji byla v obou částech popisována lehkost, druhou nejčetnější vlastností byla světlost. Celkem bylo v koloraturní části užito 835 přívlastků, v části rondo 1077 přívlastků.

Uvedené vlastnosti byly též rozděleny na specifické a nespecifické na základě shody respondentů na použití jednotlivých slovních atributů (četnosti, kolik respondentů daný přívlastek použilo při hodnocení částí árie). Nespecifické přívlastky byly použity obdobným počtem respondentů $\mathrm{k}$ popisu obou částí árie; jsou to př́ivlastky lehkost, světlost, ostrost, kulatost, tmavost (a s nižším počtem respondentů též přívlastky rychlost, vyrovnanost a mohutnost). Specifické přívlastky byly užity odlišným počtem respondentů v každé části árie; v koloraturní části uvedl vyšší počet respondentů přílastky pohyblivost, těžkost, přesnost a těžkopádnost (a též pomalost). Naopak pro rondo byly specifické přívlastky dramatičnost a vyváženost a též jasnost, výraznost a s menší mírou četnosti i srozumitelnost.

\section{Diskuse}

\section{Rozbor problémů při hodnocení vybraných vlastností}

Součástí testu bylo vyjádření respondentů k provedení testu. Nejčastější poznámka k rondu se týkala technické kvality záznamu (stáří a období nahrávky, prostředí nahrávky, umístnění a kvalita mikrofonu).

Jenom akustici (ze skupiny amatérských zpěváků) vyjádřili možnost ovlivnění hodnocení hlasu interpretky dalšími aspekty záznamu (technika záznamu, zvuk orchestru), zejména vnímání tmavých a světlých složek.

Byt’ průměrnou délku představených ukázek 24 sekund v části rondo a $25 \mathrm{~s}$ v koloratuře považujeme za dostatečnou, častým uváděným nedostatkem byla právě jejich délka. Tu vybraní posluchači ze všech skupin považovali za krátkou z hlediska vyjádření se k některým vlastnostem. Je však vhodné uvést, že průměrná doba provádění testů (v průměru jedna hodina) souvisí právě s délkou předložených podnětů, při jejich prodloužení by se výrazně zvětšila a výsledky by tak mohly být spíše negativně ovlivněny únavou respondentů.

53 V přehledu jsou vynechány vlastnosti a přívlastky obecných estetických soudů líbí/nelíbí. 
Pouze jeden amatérský zpěvák vyjádřil problém s hodnocením vhodnosti hlasu, protože by potřeboval být více seznámen s dramatickými vlastnostmi postavy a samotnou situací, která se řeší v árii. Respondent uvedl, že pak hodnotil namísto vhodnosti hlasu celkovou kvalitu, resp. jak se mu celkově líbil hlasový projev.

Čtyři vysokoškolští pedagogové prováděli hodnocení poslechových testů nepřímo s asistencí administrátora. Kromě předloženého písemného popisu vlastností mohli konzultovat význam hodnocených vlastností přímo s administrátorem. Dle této zkušenosti se na základě písemného popisu ukázala největší nejednoznačnost v pochopení vlastnosti mohutnost. Někteří potřebovali další slovní popis požadované vlastností, jiní navrhovali změnu názvu vlastnosti na „objem“, respektive velikost prostoru, do kterého se dle nich daný hlas hodí.

Koncové poznámky po koloratuře se problémů s hodnocením téměř netýkaly, většina respondentů se zaměřila na nějaký závěr z obou testů (většinou vysvětlení vnímaných vlastností či fenomény okolo postavy či árie). Ke spojitosti hodnocení tmavých a světlých složek v závislosti na kvalitě a období záznamu se vyjádřil i jeden dirigent.

\section{Rozdíly mezi respondenty}

Skupina profesionálních zpěváků byla rozdělena na dvě skupiny pedagogů, 5 patřilo do skupiny vysokoškolských pedagogů, 7 patřilo do skupiny pedagogů jiných škol. Uvedené skupiny se lišily dle počtu roků působících jako profesionální zpěváci (téměř dvojnásobný počet roků u skupiny vysokoškolských pedagogů), avšak př́liš se neodlišovaly dle počtu odučených rokủ. Lze tedy přepokládat, že skupiny zpěváků se zejména odlišují délkou své profesionální praxe, a tedy i celkovým věkem, který jsme ve studii nezjištovali.

\section{Souvislosti hodnocených vlastností}

Faktorovou analýzou lze odhalit vzájemné souvislosti v hodnocení vlastností jednotlivých typů stimulů. U ronda je nejčastěji v nejvýznamnějším - prvním faktoru hodnocena vhodnost hlasu. Lze tak předpokládat, že je nejvýznamněǰší vlastností ve variabilitě hodnocených vlastností v uvedené pasáži. Tuto vlastnost lze tedy přirovnat $\mathrm{k}$ vlastnostem, jakými jsou celková kvalita používaná v hodnoceních patologického hlasu ${ }^{54}$ nebo celkové proveden $\imath^{55}$ použité při hodnocení operního zpěvu.

Dle hodnot sycení prvního faktoru tuto vlastnost následují vlastnosti tmavé složky a mohutnost hlasu. Ze souvisejících vlastností u ronda dominovala dvojice mohutnost s tmavými složkami, a priměrenost vibrata s vhodností hlasu. Tyto kombinace zároveň rozdělily skupinu hodnotitelů na dvě výlučné skupiny z hlediska hodnocení uvedených kombinací v prvním faktoru. Ve skupině vysokoškolských pedagogů převažovalo primární zaměře-

54 FRIČ - OTČENÁŠEK, 2010, op. cit.

55 OATES et al., op. cit., s. 80-81. 
ní na společné hodnocení mohutnosti a tmavých složek, což naznačuje jejich preferenční hodnocení. Podobně leželo hodnocení barvy / tepla ve stejném faktoru s intenzitou a dynamickým rozsahem ${ }^{56}$ (hodnocení bylo též spojeno s naturálně tmavšími hlasy). Skupina ostatních profesionálů a oba dirigenti se spíše primárně soustředili na spojitost vlastností vhodnost provedeni a přměrenost vibrata. $\mathrm{V}$ naší poslední studii ${ }^{57}$ bylo hodnocení vhodnosti vibrata u skupiny hudebníků spojováno s hodnocením rezonance hlasu v recitativu, kdežto u pedagogů zpěvu v hodnocení koloraturní části jednoznačně dominovala kombinace hodnocení vhodnosti vibrata a estetického dojmu.

U koloratury je v prvním faktoru nejčastěji hodnocena pohyblivost, následuje provedeni, a pak světlost a přměřrenost vibrata. Druhý faktor relativně výrazně sytí vlastnosti mohutnost a tmavost. Vokálni nepřesnost se vyčlenila a dominovala ve třetím faktoru. Ze souvisejících vlastností u koloratury dominovala dvojice přměrenost vibrata a celkové provedeni a celkové provedeni s pohyblivostí, tmavé složky s mohutnosti a světlé složky s pohyblivostí. V prvním faktoru se u 6 z 20 respondentů projevila kombinace souvisejících vlastností priměrenost vibrata, provedeni a pohyblivost. Vhodnost vibrata a estetický dojem souvisel u hodnocení pedagogů, ${ }^{58}$ na druhé straně ve studii Wapnick et al., 1997, nenáleželo hodnocení přiměreného vibrata nikdy do stejného faktoru jako pohyblivost, ani v hodnocení celkové skupiny, a ani ve skupinách, které se lišily právě na základě příslušnosti jednotlivých hodnocených vlastností do výsledných faktorů. Existuje několik možných vysvětlení tohoto jevu. Prvním z nich by mohlo být, že uvedená studie do jednotlivých faktorů mohla zahrnout i vlastnosti, které daný faktor sytily s relativně nízkým korelačním koeficientem. To znamená, že uvedená studie hodnocení celkově 12 vlastností nerozdělila do vhodného počtu faktorů (použity byly jenom tři). Druhá příčina může být dána způsobem, dle kterého mělo být hodnocení vhodnosti vibrata prováděno. Popis nalezneme až v navazující studii Oates et al., 2006, ${ }^{59}$ jako „pravidelné a hladké zvlnění frekvence tónu“. Proto lze diskutovat, že pokud měla být hodnocena jenom pravidelnost a hladkost modulace hlasu, nemuseli hodnotitelé uplatňovat jiné faktory hodnocení ne/přiměřenosti vibrata, které jsou v jiných studiích nejčastěji spojovány s frekvencí a rozsahem modulace. ${ }^{60}$

V koloratuře je u vysokoškolských pedagogů zřetelný primární vztah mezi hodnocením tmavých složek s mohutnosti a u ostatních pedagogů vztah mezi priměreností vibrata a kvalitou provedení. U obou typů pedagogů (u 9 z 12) ale v tomto faktoru převládá hodnocení provedeni s pohyblivosti hlasu, která se tak z hlediska kvality provedeni stává zásadní vlastností. Podobně velký význam pohyblivosti potvrzují pro koloraturní část i výsledky analýzy slovního popisu. Lze se tedy domnívat, že s pohyblivostí a kvalitou bude možné spojovat i vlastnost lehkost, která měla významné postavení i v hodnocení ronda.

V rondu se tendence hodnotit společně ve stejném faktoru tmavé a světlé složky (s opačnými znaménky) vyskytuje méně než u poloviny respondentů (9 z 20; 3 vysokoškolští

56 WAPNICK et al., op. cit., s. 443-444.

57 FRIČ - PAVLECHOVÁ, op. cit.

58 FRIČ - PAVLECHOVÁ, op. cit.

59 OATES et al., op. cit., s. 80.

60 Např:: DROMEY, Christopher - CARTER, Neisha - HOPKIN, Arden: Vibrato Rate Adjustment. J. Voice, 2003 , roč. 17 , č. 2 , s. $168-178$. 
pedagogové a jen 1 profesionální zpěvák, 4 amatéři a jeden nezpěvák). V koloratuře tento počet ještě více klesá ( 6 z 20, 2 vš. pedagogové, 1 profesionální zpěvák, 2 amatérí a nezpěvák). Na základě uvedeného se potvrzuje, že tmavé a světlé složky nejsou obecně vnímány jako součást jedné dimenze, ale mohou být hodnoceny i nezávisle. Navíc se míra spojitosti hodnocení tmavých a světlých složek mění v závislosti na stimulu (může tedy souviset s technickou náročností, či s použitým výškovým rozsahem). U hodnocení tmavých a světlých složek je však nutno brát ohled i na skutečnost, že mohou být ovlivněny kvalitou záznamu a prostorovým uspořádáním při nahrávání. Uvedené zjištění naznačuje i rozbor popsaný v Garnier et al., 2007, kde vlastnosti patřící do první dimenze jasný, světlý - tmavý, temný jsou často popisovány v protichůdných významech ve smyslu vztahu k celkové kvalitě hlasu. Lze jenom diskutovat nad upřesněním jednotlivých významů, kde předpokládáme, že jedna složka této dimenze souvisí s hlasovým typem, a tedy s určitou přirozenou mírou tmavosti-světlosti - podobně jak to bylo prokázáno v předchozí studii, ${ }^{61}$ kdežto další významy této dimenze se pravděpodobně dotýkají jasu a zvonivosti jakožto specifických kvalitativních vlastností hlasu, př́padně i pozice vokálů, nebo naopak určité míry nepřirozeného „zatmaveni“, nebo přilišné světlosti - „vybledlosti“, jakožto př́klad nevhodné techniky hlasu.

Přiměrenost vibrata se ukázala jako jedna ze zásadních složek hodnocení. U relativně velké skupiny hodnotitelů ( 4 profesionální zpěváci a 2 dirigenti) byla zastoupena v hlavním faktoru hodnocení a zároveň souvisela s celkovou kvalitou provedeni v rondu i v koloratuře. Přiměrenost vibrata byla obecně i mezi skupinami nejkonzistentněji hodnocenou vlastností. Nejmenší shodu však měla skupina vysokoškolských pedagogů (nejnižší hodnota koeficientu Cronbachovo alfa CA) a skupina, kde byla dominantním faktorem hodnocení kombinace tmavých složek a mohutnosti. Na základě tohoto lze vyslovit hypotézu, že vysokoškolští pedagogové nebyli dostatečně citliví při hodnocení vibrata, či jeho hodnocení přriřknuli nižší význam. To dokladuje i jejich většinové $(4$ z 5) umístnění vibrata ve 3. faktoru v rondu a ve 3. a 4. faktoru u koloratury. Případné problémy při hodnocení přiměřenosti vibrata lze zkoumat jak prostřednictvím sledování objektivních parametrů modulace hlasu v jeho průběhu, tak i prostřednictvím hodnocení hodnotitelů. Podrobnější analýza ukázala, že někteří vysokoškolští pedagogové nehodnotili přiměřenost vibrata spojitě, resp. normálním rozložením, ale že jejich hodnocení měla spíše podobu kategorického posuzování dobré/špatné. Takový typ hodnocení degraduje použitou škálu a sám o sobě znemožňuje dostatečnou shodu, která byla vypočtena z CA.

Konkrétní spojitosti mezi hodnocením a objektivními vlastnostmi vibrata budou předmětem navazující psycho-akustické studie.

\section{Shoda hodnotitelů}

Výsledky této studie jednoznačně ukazují nejednotnost v hodnocení sledovaných vlastností mezi skupinami, a zejména ve skupině profesionálů. $\mathrm{V}$ rondu mají sice amatéri

61 FRIČ - PAVLECHOVÁ, op. cit. 
nízkou shodu, ale kromě mohutnosti jsou ostatní koeficienty větší než 0,5 . U vysokoškolských pedagogů byly všechny koeficienty velmi nízké, nejnižší byly při hodnocení vibrata a vhodnosti hlasu, naopak ostatní pedagogové a dirigenti mají u uvedených vlastností velmi dobrou shodu. Z těchto výsledků lze usuzovat na názorové rozdíly uvnitř skupin, podobně jak to dokladovala studie Wapnick et al, 1997, která ukázala rozlišné strategie hodnocení klasického zpěvu dokonce uvnitř 28 univerzitních pedagogů zpěvu. Studie dále prokázala vyšší reliabilitu hodnocení u pedagogů, kteří se primárně soustředili na provedení (vlastnosti: vyrovnanost rejstřiků, volnost hlasu v celém rozsahu a pohyblivost) než na vnitřní kvalitu (rezonance, intenzita, dynamický rozsah, barva / teplo). V porovnání s předkládanou studií se zdá, že vysokoškolští pedagogové patří víc do skupiny citlivé na intenzitu, rezonanci a dynamiku - v naší studii reprezentované primární citlivostí na mohutnost a přítomnost tmavých složek (př́ítomnost tmavých složek byla málo reliabilní i v citované studii). I přes uvedená vysvětlení mohou být uvedené rozdíly způsobeny i odlišným stavem sluchu respondentů, jejich nedostatečnou zkušeností s hodnocením na vizuálních škálách, či dalšími faktory.

Lepši shoda hodnotitelů při hodnocení koloratury by mohla být způsobena zatrénováním respondentů při předcházejícím testu ronda, ale je nutno vzít do úvahy i skutečnost, že některé vlastnosti mohly být mezi interpretkami výrazněji rozdílné v důsledku vyšší technické náročností provedení koloraturní části.

\section{Výsledné vazby mezi hodnocenými vlastnostmi}

Na základě uvedených výsledků lze usoudit, že hodnocení přiměrenosti vibrata v rondu a koloratuře souvisí s přítomností světlých složek a naopak, nesouvisí s mírou tmavých složek. Tato závislost platí i přesto, že tmavé složky záporně korelují se světlými složkami. Tuto závislost též v části rondo potvrzují výsledky faktorové analýzy. Výsledky naznačují možnou závislost přiměřenosti vibrata na světlosti, ale nezávislost na tmavosti (ta zřejmě leží v jiném faktoru). Dle výsledků pak hodnocení tmavých složek nejvíce souvisí s mohutností.

U koloratury nelze výsledky takto jednoznačně zhodnotit. Významný nezávislý faktor zde představuje vlastnost vokálni nepřesnost, která se však výrazně vyčleňuje do nezávislého faktoru pouze u skupiny ostatni pedagogové, dirigenti a amatéři (skupina s největší shodou hodnocení u přměrenosti vibrata). To lze interpretovat tak, že pro ostatní skupiny v koloratuře přiměrenost vibrata souvisela s kvalitou provedeni a pouze skupina s největší shodou dokázala vibrato hodnotit na kvalitě provedeni nezávisle. Nejvýznamnějším faktorem hodnocení koloratury je ve všech případech vlastnost pohyblivost hlasu.

\section{Společné souvislosti v hodnocení části rondo a koloratury}

Podobný způsob hodnocení mezi oběma částmi árie mají vlastnosti světlé složky, tmavé složky a mohutnost. Naopak, přiměrenost vibrata, vhodnost hlasu a vhodnost provedeni nelze 
považovat $\mathrm{v}$ různých částech árie za podobně hodnocené (korelace jsou nevýznamné i u skupin s nejvýznamnější shodou). Vzhledem k tomu, že nelze prokázat, že by tato nevýznamnost byla způsobená neshodou hodnotitelů, lze uvažovat nad tím, že hodnocení přiměrenosti vibrata (a podobně i celkového provedeni) má jiná kritéria v pomalejší části a jiné v koloraturním provedení. Podobně byl ukázán nárůst významu hodnocení vhodnosti vibrata, ${ }^{62} \mathrm{kde}$ se vibrato posunulo $\mathrm{z}$ třetího do druhého faktoru při porovnání hodnocení pedagogů mezi recitativem a koloraturním úsekem. Hodnocení vibrata však bylo v předkládané studii u testů obou částí ve stejném faktoru jako vhodnost hlasu resp. provedení, lze proto usuzovat, že vibrato je důležitým technickým (či interpretačním) prvkem, který má vliv na celkový dojem z provedení.

Hodnocená část árie má též vliv na důležitost jednotlivých vlastností. Primární hodnotící hledisko v rondu byla přítomnost tmavých složek a mohutnost hlasu (tyto složky zde však nebyly spojeny s vhodností hlasu). Oproti tomu v koloratuře bylo nejvýznamnější hodnotící hledisko celkového provedení To bylo spojeno zejména s pohyblivosti hlasu a obecně i s priměreností vibrata, které je známkou vhodnosti hlasu i v rondu. Na základě těchto poznatků lze vyslovit pro navazující výzkum výzkumnou otázku: proč se mění důležitost, hodnocení a význam jednotlivých vlastností při hodnocení pomalejší a rychlejší části?

Výraznější př́tomnost světlých složek byla v rondu spjata s hodnocením vhodnosti hlasu, ale i s celkovým provedením a s ním spjatými kvalitativně vhodnějšími vlastnostmi (príměrenost vibrata, dobrá pohyblivost) v koloraturní ćásti. Přítomnost světlých složek v rondu tak lze považovat za významný technický prvek. Z hlediska kvality provedeni koloraturní části árie podmiňuje lepší přiměrenost vibrata a pohyblivost a doprovází méně výrazná mohutnost hlasu, která je v koloratuře spíše omezující vlastností.

\section{Slovní popis}

Většinu z přílastků a vlastností uváděných respondenty s vysokou četností lze přiřadit vlastnostem popsaných studiemi v úvodu této práce. Na základě toho lze usoudit, že skupina hodnotitelů použivala $\mathrm{k}$ hodnocení zpěvního hlasu vlastnosti, které jsou obecně uznávané a sdílené; v části rondo účastníci testu nejčastěji hodnotili dech, barvu, vyślovnost, glissando, frázováni a vibrato, v koloraturní části pak účastníci testu nejčastěji hodnotili koloraturu, výšku hlasu a tón (ve smyslu kvality). Respondenti též nejčastěji užívali přílastky lehkost, kulatost a světlost, přičemž prrívlastek světlost užívali v části rondo s dvojnásobnou četností (oproti koloratuře). $\mathrm{V}$ koloratuře také byla hodnocena s výrazně větší relativní četností pohyblivost, těžkost, těžkopádnost a presnost.

Výrazné relativní rozdíly mezi užitím vlastností a př́ílastků v části rondo a koloratuře, např. u slov světlost, těžkost a celkově četné vlastnosti vibrato, podporují výsledky a závěry učiněné na základě dat z posuzovacích škál (rozdíly v důležitosti světlých složek, mohutnosti či vibrata pro posuzování jednotlivých částí). Př́vlastky a vlastnosti uvedené v části výsled-

62 FRIČ - PAVLECHOVÁ, op. cit. 
ky lze na základě vysoké četnosti v tomto testu považovat za možné zástupce vlastností užívaných k popisu kvality zpěvu z technického i interpretačního hlediska, a lze je tak např. užít jako podklad k vymezení hodnotících kategorií a tematických okruhů v dalších studiích. Podrobnější zpracování těchto kvalitativních dat a vlastností je tak plánováno jako předmět další, navazující studie.

\section{Limitace studie a doporučení do další práce}

Užité nahrávky byly pořízeny různou technikou v různých obdobích. Hodnocené vlastnosti tak mohou být ovlivněny technickým provedením nahrávky (frekvenční rozsah, zkreslení, efekt blízkosti), což mohlo změnit např. relativní poměr světlých a tmavých složek. Protože však cílem studie byl výzkum relativních rozdílů v hodnocení pěveckého provedení různými skupinami respondentů, nikoli hodnocení interpreta, toto nepředstavovalo výrazný problém, i když kvalita nahrávek mohla ovlivnit hodnocení míry konkrétní vlastnosti u jednotlivých záznamů.

Chyba poslechového hodnocení mohla být též způsobena odlišným stavem sluchu hodnotitelů či různou hlasitostí poslechu. Např́č skupinami lze předpokládat nesystematické rozložení těchto chyb a tyto faktory se tak mohly projevit větším rozptylem hodnocených vlastností.

Neshoda respondentů mohla nastat i v důsledku postupného zácviku respondentů v průběhu výkonu poslechového testu (respondenti před prvním poslechovým testem neprošli řízeným zácvikem na zácvikových stimulech). Opakované (retestové) hodnocení nebylo prováděno z důvodu velkých časových nároků.

\section{Závěr}

Technická kvalita nahrávek a období mohla ovlivnit např. hodnocení světlých a tmavých složek. Hodnoty těchto vlastností tak mohou být předmětem diskuse.

Z provedeného výzkumu vyplývá, že shoda mezi malými skupinami pedagogů a profesionálních zpěváků je spiše ojedinělou záležitostí. Vy̌šší míru shody lze pozorovat až např́ić většími skupinami hodnotitelů a tato shoda není závislá na profesním působení. Zdá se, že v míře shody sehrává důležitou úlohu poslechový zácvik. Jedním z výstupů předkládané studie je existence sady zvukových ukázek, které byly shodně ohodnoceny $\mathrm{v}$ poslechových testech.

U pomalejš́ části rondo panovala nižší shoda hodnocení než u koloraturní části. Tento jev lze vysvětlit tím, že v koloraturní části byly přítomny prvky, na nichž se respondenti lépe shodli, avšak lze jej vysvětlit též tím, že shoda byla způsobena předchozím zácvikem respondentů při hodnocení části rondo.

U skupin hodnotitelů je možné rozlišit skupinu posluchačů, která se zaměřila na kombinaci tmavosti a mohutnosti a na skupinu, která se zaměřila na přiměrenost vibrata a vhodnost 
hlasu. Toto rozdělení posluchačů přetrvávalo i v hodnocení koloratury, u ní však bylo hodnocení celkového provedeni převážně spojeno s hodnocením pohyblivosti hlasu. Výsledky ukazují, že zaměření na přměřrenost vibrata bylo spojeno s hodnocením celkového provedení a vhodnosti hlasu, ovšem nikoliv u skupiny preferující tmavé a mohutné hlasy.

Výsledky celkových hodnocení u skupiny všech hodnotitelů a u skupin s nejlepší shodou (určených na základě faktorové analýzy) odhalují, že v pomalejší části byl celkově větší důraz kladen na tmavé složky a mohutnost hlasu, kdežto v koloratuře byl celkově větší důraz kladen na celkové provedení, pohyblivost a částečně i přiměrenost vibrata. U skupiny s nejshodnějším hodnocením priměřnosti vibrata (ostatní pedagogové, dirigenti a amatérští zpěváci) představovalo zvláštní faktor hodnocení koloratury, které bylo významně spojeno s hodnocením celkového provedení.

Přítomnost světlých složek v rondu souvisí s celkovou kvalitou provedení koloratury a též s adekvátností vibrata. Tmavé složky souvisely zejména s hodnocením mohutnosti. Vzájemné protichůdné hodnocení přítomnosti tmavých a světlých složek je výrazné v pomalejší části ronda, ale uvedená protichůdnost se vytrácí při hodnocení koloratury. Na základě toho lze předpokládat, že tmavé a světlé složky jsou relativně nezávislé, a tedy netvoří opačné konce stejné dimenze.

Podrobnější souvislosti poslechového hodnocení nahrávek s akustickými vlastnostmi, jakož i expertní rozbor slovních hodnocení vzhledem k jednotlivým nahrávkám a skupinám hodnotitelů budou předmětem výzkumu v navazující studii.

\section{Poděkování}

Studie vznikla na Akademii múzických umění v Praze v rámci projektu „Zvuková kvalita“ podpořeného z prostředků Institucionální podpory na dlouhodobý rozvoj výzkumné organizace, kterou poskytlo MŠMT v r. 2018. Děkujeme vedoucímu MARC Ing. Z. Otčenáškovi a MgA. V. Hruškovi za odborné konzultace a hodnotitelům za trpělivost při provádění poslechových testů.

\section{Bibliography}

CAO, Chuan - LI, Ming - LIU, Jian - YAN, Yonghong. An objective singing evaluation approach by relating acoustic measurements to perceptual ratings, In: 9th Annual Conference of the International Speech Communication Association, Brisbane: INTERSPEECH, 2008, s. 2058-2061.

EKHOLM, Elizabeth - PAPAGIANNIS, C. Georgios - CHAGNON, P. Francoise. Relating objective measurements to expert evaluation of voice quality in Western classical singing: critical perceptual parameters, J Voice, 1998, roč. 12, č. 2, s. 182-196.

FRIČ, Marek - OTČENÁŠEK, Zdeněk. Přehled metodických postupů subjektivního popisu vlastností hlasových projevi̊ v oblasti poruch, patologie a terapie hlasu. Otorinolaryng. a Foniat. (Prague), 2010. roč. 59, č. 4, s. 214-224. 
FRIČ, Marek - OTČENÁŠEK, Zdeněk - KADLECOVÁ, Klára. Poslechové hodnocení vlastností zpěvu - předběžná studie. In: Proceedings of the 6th International Symposium: Material - Acoustics - Place, 2011. Technical University in Zvolen, s. 83-93.

FRIČ, Marek - KADLECOVÁ A. Klára. Porovnání vlastností a parametrů hlasu pěvecky trénovaných a netrénovaných žen. Akustické listy, 2012. roč. 18, č. 2-3, s. 5-24.

FRIČ, Marek. Strategie poslechového hodnocení rezonance hlasu. In: Nové trendy akustického spektra - vedecký recenzovaný zbornik, Zvolen: Material - Acoustics - Place, 2014, s. 73-80.

FRIČ, Marek - PAVLECHOVÁ, Angelika. Listening evaluation and classification of female singing voice categories, Logopedics Phoniatrics Vocology, (in press).

GARNIER, Maeva - HENRICH, Nathalie - CASTELLENGO, Michele - SOTIROPOULO, David - DUBOIS, Daniele. Characterisation of Voice Quality in Western Lyrical Singing: from Teachers' Judgements to Acoustic Descriptions, Journal of Interdisciplinary Music Studies, 2008, roč. 1 , č. 2, s. 62-91.

HENRICH, Nathalie - BEZARD, Pascal - EXPERT, Robert - GARNIER, Maeva - GUERIN, Christian - PILLOT, Claire - QUATTROCCHI, Sophie. Towards a Common Terminology to Describe Voice Quality in Western Lyrical Singing: Contribution of a Multidisciplinary Research Group, Journal of Interdisciplinary Music Studies, 2008, roč. 2, vol. 1,2, s. 71-93.

HIRANO, Minoru. Clinical Examination of Voice. 1. vyd. Vienna: Vienna Springer, 1981, s. 81-84.

KOKOTSAKI, Dimitra - DAVIDSON, W. Jane - COIMBRA, Daniela. Investigating the Assessment of Singers in a Music College Setting: The Students' Perspective, Research Studies in Music Education, 2001, roč. 16, č. 1, s. 15-32.

KULANOVÁ, Angelika - FRIČ, Marek. Komparácia náčuvových a počítačových akustických hodnotení speváckych vlastností hlasu. DISPUTATIONES SCIENTIFICAE UNIVERSITATIS CATHOLICAE IN RUŽOMBEROK, 2012, roč. 12, č. 2, s. 79-98.

KULHÁNEK, Tomáš - FRIČ, Marek - OTČENÁŠEK, Jan. Software pro tvorbu percepčnich testů na webovém rozhrani - software; MARC-Technologický list čís. 82/16, Praha: MARC HAMU, 2016.

OATES, M. Jennifer - BAIN, Belinda - DAVIS, Pamela - CHAPMA, Janice - KENNY, Dianna. Development of an auditory-perceptual rating instrument for the operatic singing voice, J Voice, 2006, roč. 20, č. 1, s. 71-81.

SHEWELL, Christina. Voice Work: Art and Science in Changing Voices. 1. vyd. New Jersey: Wiley-Blackwell. s. 82-103.

SWAROWSKY, Hans. Vorbemerkung zu W. A. Mozarts Solfeggi (K.V: 393); Wien, 1956.

SHORT, C. Jeremy. et al. Construct validation using computer-aided text analysis (CATA) an illustration using entrepreneurial orientation. Organizational Research Methods, 2010, roč. 13, č. 2, s. 320-347.

ŠTĚPÁNEK, Jan - MORAVEC, Ondřej. Barva hudebniho zvuku a jeji slovni popis - Výsledky grantového projektu GAČR 202/02/1370. 1. vyd. Praha: Hudební fakulta Akademie múzických umění v Praze, 2005, s. 47.

WAPNICK, Joel - EKHOLM, Elizabeth. Expert consensus in solo voice performance evaluation, J Voice, 1997, roč. 11, č. 4, s. 429-436. 


\section{Apendix}

\section{Informace o hodnotitelích}

\begin{tabular}{|l|l|l|c|c|c|c|c|c|}
\hline \hline IDS & Pohl. & Popis & $\begin{array}{c}\text { HAMU } \\
\text { pedagog }\end{array}$ & $\begin{array}{c}\text { pedagog } \\
\text { zpěvu }\end{array}$ & $\begin{array}{c}\text { prof. } \\
\text { zpěvák }\end{array}$ & $\begin{array}{c}\text { amat. } \\
\text { zpěvák }\end{array}$ & $\begin{array}{c}\text { čas (min) } \\
\text { rondo }\end{array}$ & $\begin{array}{c}\text { čas (min) } \\
\text { koloratura }\end{array}$ \\
\hline \hline ZH1 & F & ped. HAMU & 18 & 21 & 42 & 0 & 67 & 52 \\
\hline ZH2 & M & ped. HAMU & 2 & 12 & 42 & 0 & 47 & 30 \\
\hline ZH3 & M & ped. HAMU & 9 & 20 & 46 & 10 & 41 & 52 \\
\hline ZH4 & F & ped. HAMU & 5 & 10 & 27 & 0 & 44 & 47 \\
\hline ZH5 & F & ped. HAMU & 40 & 40 & 30 & 0 & 37 & 48 \\
\hline ZP1 & F & prof. zpěvák & 0 & 25 & 28 & 11 & 53 & 74 \\
\hline ZP2 & F & prof. zpěvák & 0 & 16 & 28 & 12 & 101 & 88 \\
\hline ZP3 & F & prof. zpěvák & 0 & 5 & 10 & 0 & 56 & 47 \\
\hline ZP4 & F & prof. zpěvák & 0 & 6 & 8 & 0 & 83 & 95 \\
\hline ZP5 & M & prof. zpěvák & 0 & 15 & 35 & 16 & 49 & 65 \\
\hline ZP6 & F & prof. zpěvák & 0 & 15 & 0 & 5 & 27 & 44 \\
\hline ZP7 & F & prof. zpěvák & 0 & 45 & 30 & 5 & 70 & 55 \\
\hline D1 & M & dirigent & 0 & 0 & 0 & 0 & 34 & 75 \\
\hline D2 & M & dirigent & 0 & 0 & 0 & 33 & 145 & 153 \\
\hline \hline A1 & M & am. zp. + akustik & 0 & 0 & 0 & 24 & 61 & 47 \\
\hline A2 & M & am. zp. + akustik & 0 & 0 & 0 & 6 & 25 & 31 \\
\hline A3 & M & am. zp. + foniatr & 0 & 0 & 0 & 10 & 69 & 43 \\
\hline A4 & F & am. zp. & 0 & 0 & 0 & 12 & 81 & 104 \\
\hline A5 & F & am. zp. & 0 & 0 & 0 & & 58 & 37 \\
\hline \hline J1 & M & student zvuk.tv. & 0 & 0 & 0 & 0 & 65 & 52 \\
\hline \hline $\begin{array}{l}\text { Celk } \\
\text { čas. min }\end{array}$ & \multirow{2}{*}{2452} & Prům. & 3.7 & 10.8 & 15.7 & 7.4 & 60.7 & 62.0 \\
\hline čas \\
v hod.:
\end{tabular}

Tab. 3 Charakterizace hodnotitelů (respondentů), čas hodnocení jednotlivých testů a jejich průměrné hodnoty a směrodatné odchylky (SD). 


\section{Zpracování dat}

\section{Faktorová analýza hodnocení jednotlivých hodnotitelů}

Hodnoty odpovědí všech respondentů byly vyhodnoceny na základě výsledků faktorové analýzy (SW STATISTICA 6.0, metoda varimax normalised). Vhodný počet faktorů byl určen pro každou část textu a každého hodnotitele inspekcí vlastních hodnot faktorů. $\mathrm{V}$ části rondo tak bylo u všech 5 škál možné u většiny hodnotitelů rozlišit alespoň 3 faktory a u šesti škál hodnocení koloratury alespoň 4 faktory.

$\underline{\text { Shoda hodnotitelů }}$

Shoda hodnotitelů byla stanovena koeficientem Cronbachova alfa vypočteným pro skupinu všech 20 hodnotitelů, pro profesní podskupiny i pro podskupiny určené na základě výsledků faktorové analýzy.

\section{Vyhodnocení výsledků percepčních testů}

Před vyhodnocením byly vypočteny střední hodnoty hodnocení (průměr či medián, dle normality rozdělení) pro skupinu všech 20 hodnotiteli̊ a též pro jednotlivé podskupiny hodnotitelů vykazujících významnější shodu (Cronbachovo $\alpha>0,65$ ). Tyto hodnoty pak byly užity $\mathrm{k}$ analýze vzájemných vztahů mezi jednotlivými vlastnostmi v rámci každého testu i mezi oběma testy (Pearsonova korelace). K analýze struktury hodnocení všech 20 hodnotitelů a analýze podobnosti hodnotících skupin byla užita faktorova analýza.

\section{Zpracování slovního popisu}

Za účelem upřesnění hodnotících kategorií a tematických okruhů užívaných respondenty byla v práci provedena analýza slovních hodnocení, které respondenti během testu zapisovali do textového pole. Tato analýza byla provedena rozborem získaných vět metodou korpusové frekvenční analýzy četnosti podstatných jmen (hodnocené vlastnosti) a přídavných jmen (přívlastky hodnocených vlastností) v korpusu - metoda CATA ${ }^{63}$ (Short et al., 2010). Analýza byla dále podpořena analýzou podílu respondentů užívajících dané slovo.

Vlastnosti a přívlastky s nejvyšší četností a vlastnosti a přívlastky s vysokým podílem respondentů užívajících dané slovo byly považovány za významné pro respondenty z hlediska hodnocení předložených zvuků; vyšší relativní četnost určité vlastnosti či přívlastku v jedné části árie oproti druhé pak je interpretována tak, že daná vlastnost je pro hodnocení dané části významnější; k vyjádření relativní četnosti byla užita procentní četnost daného deskriptoru vzhledem k nejčetnější vlastnosti.

63 Ang.: Computer aided text analysis (CATA; počítačová textová analýza). 
V tabulkách jsou z důvodu významnosti uváděny pouze př́ílastky, které byly respondenty užity s absolutní četností větší než 15 a vlastnosti s absolutní četnosti větší než 10 . $\mathrm{Z}$ analýzy byly navíc vyloučeny přívlastky vztahující se $\mathrm{k}$ hodnocení estetického působení (krásný, pěkný) a míry (veliký, malý); tyto vlastnosti nebyly předmětem výzkumu. Pro účely prezentace výsledků byl u podstatných jmen uvedených k popisu vlastností sjednocen tvar a u přílastků (přídavná jména) byl proveden převod do podoby abstraktních podstatných jmen, která odpovídají vlastnostem hodnoceným daným př́ílastkem.

\section{Analytické výsledky}

\section{Rozbor hodnocení jednotlivých hodnotitelů - faktorová analýza}

Výsledky faktorové analýzy ${ }^{64}$ hodnocení jednotlivých hodnotitelů jsou uvedeny v tabulce 4 (uvedeny koeficienty sycení faktorů vlastnostmi pro oba testy). Barvou a typem písma je znázorněna příslušnost škálovaných vlastností k jednotlivým faktorům. Vlastnosti byly považovány za příslušné faktorům při hodnotách korelací vy̌šíích než 0,65 .

64 Faktorová analýza je statistická metoda, která popisuje variabilitu dat. V našem př́ípadě hledá související hodnocené vlastnosti, které spojí do stejného faktoru hodnocení. Počet nalezených faktorů ukazuje, v kolika nejvýznamnějších oblastech se celkové hodnocení všech vlastností nejvíce liší - čím je daná celková variabilita hodnocení sledovaných stimulů. Výsledné faktory nakonec sdružují vlastnosti, jejichž hodnocení společně souvisí, ale zároveň je odlišné od jiných vlastností patřících do jiného faktoru. Pořadové číslo faktoru označuje, jak velký význam měly pro hodnotitele vlastnosti přináležející danému faktoru (sytí daný faktor), vzhledem k celkovému hodnocení všech vlastností. Význam faktoru je většinou popsán v podobě \%, která vysvětlují, jak velkou míru variability dat daný faktor postihuje. 


\begin{tabular}{|c|c|c|c|c|c|c|c|c|c|c|c|c|}
\hline \multirow[b]{2}{*}{$\underline{\underline{Q}}$} & \multicolumn{5}{|c|}{ Rondo } & \multicolumn{7}{|c|}{ Koloratura } \\
\hline & 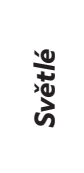 & $\begin{array}{l}\text { ¿े } \\
\text { हे } \\
\text { E }\end{array}$ & 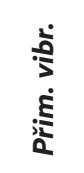 & 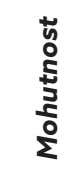 & 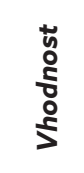 & 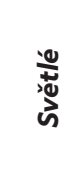 & 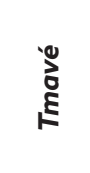 & 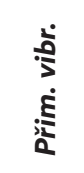 & 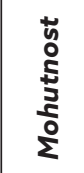 & 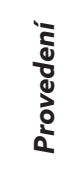 & 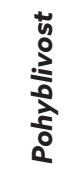 & 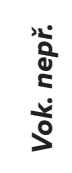 \\
\hline ZH1 & 0.80 & -0.97 & 0.93 & $\underline{0.87}$ & 0.86 & -0.93 & $\underline{0.90}$ & $\begin{array}{c}-0.93 \\
\end{array}$ & $\underline{0.78}$ & 0.82 & 0.84 & 0.94 \\
\hline ZH2 & 0.98 & 0.98 & 0.81 & 0.75 & 0.76 & 0.79 & 0.94 & 0.87 & 0.95 & 0.71 & 0.95 & 0.68 \\
\hline ZH3 & -0.69 & 0.98 & 0.97 & 0.90 & $\overline{0.91}$ & $x$ & 0.81 & 0.94 & 0.94 & -0.95 & -0.68 & 0.96 \\
\hline ZH4 & -0.95 & 0.95 & 0.97 & 0.77 & 0.91 & -0.89 & 0.97 & 0.87 & 0.93 & 0.80 & 0.98 & 0.97 \\
\hline ZH5 & 0.70 & 0.90 & 0.78 & 0.90 & 0.91 & -0.93 & 0.79 & -0.95 & 0.94 & 0.95 & -0.77 & $x$ \\
\hline ZP1 & 0.88 & 0.91 & 0.96 & 0.94 & 0.76 & 0.90 & 0.94 & 0.84 & 0.94 & 0.84 & 0.92 & -0.90 \\
\hline ZP2 & -0.80 & 0.91 & 0.94 & 0.97 & 0.97 & 0.91 & -0.98 & 0.95 & -0.68 & 0.89 & 0.89 & -0.98 \\
\hline ZP3 & 0.93 & 0.86 & 0.64 & 0.97 & 0.95 & 0.84 & -0.93 & 0.87 & -0.73 & 0.89 & 0.76 & 0.99 \\
\hline ZP4 & -0.94 & 0.69 & 0.77 & 0.94 & $\underline{-0.70}$ & -0.89 & 0.93 & -0.84 & 0.80 & -0.76 & 0.90 & 0.98 \\
\hline$Z P 5$ & 0.92 & 0.94 & 0.96 & $x$ & 0.71 & 0.79 & -0.93 & 0.76 & -0.74 & $\underline{0.88}$ & 0.91 & 0.92 \\
\hline ZP6 & 0.94 & 0.93 & $\underline{0.95}$ & 0.66 & $\underline{0.89}$ & 0.81 & -0.90 & $\underline{0.87}$ & 0.97 & $\underline{0.91}$ & $\underline{0.72}$ & 0.96 \\
\hline ZP7 & 0.70 & -0.90 & 0.98 & 0.95 & 0.96 & 0.97 & 0.92 & 0.75 & 0.89 & 0.85 & 0.94 & -0.95 \\
\hline$\underline{D 1}$ & 0.90 & 0.86 & $\underline{0.96}$ & 0.97 & $\underline{0.85}$ & $\underline{0.76}$ & 0.92 & $\underline{0.95}$ & 0.85 & $\underline{0.87}$ & 0.94 & -0.96 \\
\hline D2 & 0.98 & -0.66 & -0.91 & -0.95 & -0.95 & -0.95 & 0.96 & 0.80 & -0.69 & 0.94 & 0.92 & -0.99 \\
\hline$\underline{A 1}$ & -0.89 & $\underline{0.90}$ & $\begin{array}{l}0.74 \\
\end{array}$ & 0.87 & 0.88 & 0.86 & $\begin{array}{l}-0.91 \\
\end{array}$ & 0.87 & $\mathrm{x}$ & 0.90 & $\underline{0.95}$ & 0.93 \\
\hline A2 & 0.88 & 0.87 & 0.93 & $\underline{0.95}$ & 0.94 & -0.92 & 0.94 & 0.96 & 0.87 & 0.82 & -0.70 & -0.97 \\
\hline $\mathrm{A3}$ & $\underline{0.98}$ & -0.97 & 0.91 & -0.86 & 0.91 & $\underline{0.93}$ & -0.93 & 0.89 & 0.99 & 0.93 & $\underline{0.86}$ & 0.72 \\
\hline $\mathrm{A4}$ & -0.96 & 0.80 & -0.91 & -0.97 & -0.92 & 0.91 & -0.96 & 0.86 & $\underline{0.90}$ & 0.82 & -0.68 & 0.98 \\
\hline$\overline{A 5}$ & 0.79 & $\overline{-0.89}$ & 0.94 & -0.95 & $\overline{0.84}$ & -0.71 & 0.88 & $\mathrm{x}$ & -0.93 & -0.91 & -0.79 & 0.95 \\
\hline $\mathrm{J} 1$ & -0.79 & 0.82 & 0.84 & 0.88 & -0.81 & 0.94 & -0.87 & 0.94 & $\begin{array}{l}-0.99 \\
\end{array}$ & 0.91 & 0.70 & 0.98 \\
\hline
\end{tabular}

Tab. 4 Výsledky faktorové analýzy hodnocení jednotlivých respondentů pro oba testy. První faktor - modrá (podtrženo a tučně); druhý faktor - červená (tučně a kurzívou); třetí faktor - oranžová (normální); čtvrtý faktor - zelená (kurzívou). Barevně jsou značeny př́slušnosti k jednotlivým faktorům hodnocení: modrá (podtrženo a tučně) - první faktor, červená (tučně a kurzívou) - druhý faktor, oranžová (normální) - třetí faktor, zelená (kurzívou) - čtvrtý faktor. 
V tabulce 5 jsou shrnuty výsledky hodnot sycení jednotlivých faktorů hodnocení ronda, v tabulce 6 pro koloraturu. Je uvedena četnost, se kterou byly v daném faktoru vlastnosti zastoupeny. Součty všech dvoukombinací výskytu jednotlivých hodnocených vlastností jsou uvedeny v části tabulce 2D-sum. V části 2D-FA1 jsou uvedeny četnosti společného sycení hodnocených vlastností jenom prvního faktoru.

\begin{tabular}{|c|c|c|c|c|c|c|}
\hline$N=20$ & Fakt./Vlast. & Světlé & Tmavé & Přim. vib. & Mohutnost & $\begin{array}{c}\text { Vhodnost } \\
\text { hlasu }\end{array}$ \\
\hline \multirow{4}{*}{$\begin{array}{l}\stackrel{\bar{c}}{\bar{d}} \\
\text { 心े }\end{array}$} & FA1 & 7 & 11 & 7 & 10 & 12 \\
\hline & FA2 & 5 & 5 & 5 & 6 & 7 \\
\hline & FA3 & 8 & 4 & 8 & 4 & 1 \\
\hline & $\mathrm{NaN}$ & 0 & 0 & 0 & 0 & 0 \\
\hline \multirow{5}{*}{ 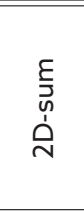 } & Světlé & 0 & 10 & 1 & 4 & 3 \\
\hline & Tmavé & 0 & 0 & 0 & 13 & 3 \\
\hline & Prim. vib. & 0 & 0 & 0 & 0 & 11 \\
\hline & Mohutnost & 0 & 0 & 0 & 0 & 3 \\
\hline & Vhodnost hlasu & 0 & 0 & 0 & 0 & 0 \\
\hline \multirow{5}{*}{$\begin{array}{l}\text { 㐫 } \\
\text { 市 } \\
\text { N }\end{array}$} & Světlé & 0 & 6 & 0 & 4 & 3 \\
\hline & Tmavé & 0 & 0 & 0 & 8 & 3 \\
\hline & Přim. vib. & 0 & 0 & 0 & 0 & 7 \\
\hline & Mohutnost & 0 & 0 & 0 & 0 & 3 \\
\hline & Vhodnost hlasu & 0 & 0 & 0 & 0 & 0 \\
\hline
\end{tabular}

Tab. 5 Rozbor výsledků faktorové analýzy, sycení jednotlivých faktorů testu rondo. 


\begin{tabular}{|c|c|c|c|c|c|c|c|c|}
\hline $\mathrm{N}=20$ & Fakt./Vlast. & Světlé & Tmavé & $\begin{array}{l}\text { Přiměře- } \\
\text { nost vib. }\end{array}$ & Mohutnost & Provedení & $\begin{array}{c}\text { Pohybli- } \\
\text { vost }\end{array}$ & $\begin{array}{c}\text { Vokál. } \\
\text { nepřesnost }\end{array}$ \\
\hline \multirow{5}{*}{ 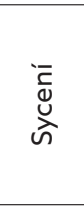 } & FA1 & 10 & 7 & 8 & 6 & 11 & 13 & 0 \\
\hline & FA2 & 3 & 8 & 2 & 11 & 4 & 3 & 2 \\
\hline & FA3 & 2 & 3 & 4 & 1 & 4 & 0 & 11 \\
\hline & FA4 & 4 & 2 & 5 & 1 & 1 & 4 & 6 \\
\hline & $\mathrm{NaN}$ & 1 & 0 & 1 & 1 & 0 & 0 & 1 \\
\hline \multirow{5}{*}{ 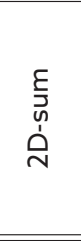 } & Světlé & 0 & 7 & 5 & 3 & 6 & 10 & 0 \\
\hline & Tmavé & 0 & 0 & 0 & 11 & 0 & 2 & 0 \\
\hline & \begin{tabular}{|l|} 
Přiměře- \\
nost vib. \\
\end{tabular} & 0 & 0 & 0 & 0 & 13 & 6 & 1 \\
\hline & Mohutnost & 0 & 0 & 0 & 0 & 0 & 1 & 0 \\
\hline & Provedení & 0 & 0 & 0 & 0 & 0 & 12 & 0 \\
\hline \multirow{5}{*}{$\begin{array}{l}\text { 管 } \\
\text { 仓 }\end{array}$} & Světlé & 0 & $\underline{4} \underline{4}$ & 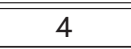 & 2 & $\underline{\overline{6}}$ & 7 & 0 \\
\hline & Tmavé & 0 & 0 & 0 & 5 & 0 & 2 & 0 \\
\hline & $\begin{array}{l}\text { Přiměře- } \\
\text { nost vib. }\end{array}$ & 0 & 0 & 0 & 0 & 8 & $\underline{6}$ & 0 \\
\hline & Mohutnost & 0 & 0 & 0 & 0 & 0 & 1 & 0 \\
\hline & Provedení & 0 & 0 & 0 & 0 & 0 & 9 & 0 \\
\hline \multirow{4}{*}{$\begin{array}{l}\frac{2}{4} \\
\text { 市 } \\
\text { ه }\end{array}$} & Světlé & 0 & 2 & 0 & 1 & 0 & 0 & 0 \\
\hline & Tmavé & 0 & 0 & 0 & 6 & 0 & 0 & 0 \\
\hline & $\begin{array}{l}\text { Přiměře- } \\
\text { nost vib. }\end{array}$ & 0 & 0 & 0 & 0 & 1 & 0 & 0 \\
\hline & Provedení & 0 & 0 & 0 & 0 & 0 & 3 & 0 \\
\hline
\end{tabular}

Tab. 6 Rozbor výsledků faktorové analýzy, sycení jednotlivých faktorů testu koloratura. 


\section{Shoda hodnotitelů}

Shoda hodnotitelů, vyjádřená koeficientem Cronbachova alfa (CA), je pro jednotlivé skupiny hodnotitelů i pro skupinu všech hodnotitelů a uvedená v tabulce 7. Společná shoda všech 20 respondentů byla pro všechny vlastnosti (kromě mohutnosti) vyhodnocena jako dobrá (CA > 0,7), u mohutnosti byla shoda vyhodnocena jako použitelná $(\mathrm{CA}>0,65)$.

\begin{tabular}{|c|c|c|c|c|c|c|c|}
\hline Skupina & $\mathbf{N}$ & Světlé & Tmavé & Přim. vib. & Mohut. & $\begin{array}{l}\text { Vhod. } \\
\text { hlasu }\end{array}$ & Resp. \\
\hline Všichni & 20 & 0.717 & 0.809 & 0.878 & 0.655 & 0.756 & všech 20 resp. \\
\hline ZH & 5 & 0.415 & 0.490 & -1.000 & 0.189 & -0.002 & ZH1-5 \\
\hline ZP & 7 & 0.444 & 0.420 & 0.862 & $\underline{0.426}$ & $\underline{0.715}$ & ZP1-7 \\
\hline D & 2 & 0.208 & 0.350 & 0.558 & -0.228 & 0.519 & D1-2 \\
\hline A & 5 & 0.539 & 0.684 & 0.561 & 0.380 & 0.655 & A1-5 \\
\hline $\mathrm{ZH}+\mathrm{ZP}$ & 12 & 0.677 & 0.712 & 0.799 & 0.610 & 0.615 & ZH1-5 + ZP1-7 \\
\hline ZH+D & 7 & 0.427 & 0.610 & 0.316 & 0.329 & 0.253 & ZH1-5 + D1-2 \\
\hline $\mathrm{ZH}+\mathrm{A}$ & 10 & 0.565 & 0.716 & 0.503 & 0.419 & 0.568 & ZH1-5 + A1-7 \\
\hline$Z P+D$ & 9 & 0.478 & 0.580 & $\underline{0.892}$ & 0.530 & 0.815 & ZP1-7 + D1-2 \\
\hline ZP+A & 12 & 0.626 & $\underline{0.718}$ & 0.882 & 0.491 & 0.771 & ZP1-7 + A1-5 \\
\hline$D+A$ & 7 & 0.581 & 0.667 & 0.729 & 0.336 & 0.727 & $\mathrm{D} 1-2+\mathrm{A} 1-5$ \\
\hline ZH+ZP+D & 14 & 0.674 & 0.751 & 0.848 & 0.649 & 0.732 & ZH1-5 + ZP1-7 + D1-2 \\
\hline $\mathrm{ZH}+\mathrm{ZP}+\mathrm{A}$ & 17 & $\underline{0.727}$ & $\underline{0.798}$ & 0.855 & 0.640 & 0.734 & ZH1-5 + ZP1-7 + A1-5 \\
\hline$Z P+D+A$ & 14 & 0.649 & 0.748 & 0.902 & 0.562 & $\underline{0.833}$ & $\mathrm{ZH} 1-5+\mathrm{D} 1-2+\mathrm{A} 1-5$ \\
\hline $\begin{array}{l}R \text {-Světlé / } \\
\text { Tmavé }\end{array}$ & 10 & $\underline{0.672}$ & 0.696 & 0.750 & 0.303 & 0.528 & $\begin{array}{l}\text { ZH1 ZH3 ZH4 ZP2 ZP7 } \\
\text { A1 A3 A4 A5 J1 }\end{array}$ \\
\hline $\begin{array}{l}\text { R-Tmavé / Mo- } \\
\text { hutnost }\end{array}$ & 13 & 0.539 & $\underline{0.717}$ & 0.826 & $\underline{0.523}$ & 0.648 & $\begin{array}{l}\text { ZH2 ZH3 ZH4 ZH5 ZP1 } \\
\text { ZP3 ZP4 ZP6 D1 D2 } \\
\text { A2 A3 J1 }\end{array}$ \\
\hline $\begin{array}{l}R \text {-Přim.vib. / } \\
\text { Vhod.hlasu }\end{array}$ & 11 & 0.522 & 0.639 & $\underline{0.896}$ & 0.397 & 0.781 & $\begin{array}{l}\text { ZP1 ZP2 ZP3 ZP5 ZP6 } \\
\text { ZP7 D1 D2 A1 A2 A5 }\end{array}$ \\
\hline $\begin{array}{l}\text { R-Fa1 - Tmavé / } \\
\text { Mohutnost }\end{array}$ & 8 & 0.231 & 0.671 & 0.570 & 0.480 & 0.070 & $\begin{array}{llll}Z H 2 & Z H 3 & Z H 4 & \text { ZH5 } \\
\text { ZP3 A2 A3 J1 } & \\
\end{array}$ \\
\hline $\begin{array}{l}\text { R-Fa1 - Přim.vib. } \\
\text { /Vhod.hlasu }\end{array}$ & 7 & 0.418 & 0.237 & 0.840 & 0.061 & $\underline{0.788}$ & $\begin{array}{l}\text { ZP1 ZP2 ZP6 ZP7 D1 } \\
\text { D2 A5 }\end{array}$ \\
\hline
\end{tabular}

Tab. 7 Shoda hodnotitelů a rozdělení na skupiny dle hodnocení ronda.

Shoda hodnotitelů pro hodnocení koloratury je uvedena v tabulce 8. 


\begin{tabular}{|c|c|c|c|c|c|c|c|c|c|}
\hline Skupina & $\mathbf{N}$ & Světlé & Tmavé & $\begin{array}{l}\text { Přim. } \\
\text { vib. }\end{array}$ & Mohut. & Proved. & Pohybl. & $\begin{array}{c}\text { Vokál. } \\
\text { nepřes. }\end{array}$ & Resp. \\
\hline Všichni & 20 & 0.757 & 0.866 & 0.885 & 0.783 & 0.918 & 0.926 & 0.859 & všech 20 \\
\hline ZH & 5 & 0.391 & 0.630 & 0.013 & 0.588 & 0.782 & 0.685 & 0.488 & $\mathrm{ZH} 1-5$ \\
\hline ZP & 7 & 0.681 & $\underline{0.789}$ & $\underline{0.807}$ & 0.549 & $\underline{0.803}$ & $\underline{0.869}$ & 0.722 & ZP1-7 \\
\hline $\mathbf{D}$ & 2 & -0.008 & 0.244 & 0.747 & 0.636 & 0.730 & 0.773 & 0.769 & D1-2 \\
\hline A & 5 & 0.160 & 0.649 & 0.794 & 0.092 & 0.706 & 0.711 & 0.688 & A1-5 \\
\hline $\mathrm{ZH}+\mathrm{ZP}$ & 12 & $\underline{0.742}$ & $\underline{0.836}$ & 0.759 & $\underline{0.747}$ & 0.851 & 0.891 & 0.792 & ZH1-5 + ZP1-7 \\
\hline ZH+D & 7 & 0.589 & 0.637 & 0.481 & 0.673 & 0.811 & 0.835 & 0.661 & ZH1-5 + D1-2 \\
\hline $\mathrm{ZH}+\mathrm{A}$ & 10 & 0.580 & 0.782 & 0.691 & 0.628 & 0.841 & 0.822 & 0.781 & ZH1-5 + A1-7 \\
\hline ZP+D & 9 & 0.727 & 0.797 & 0.866 & 0.622 & 0.881 & 0.912 & 0.778 & ZP1-7 + D1-2 \\
\hline$Z P+A$ & 12 & 0.690 & 0.863 & 0.892 & 0.551 & 0.877 & 0.898 & 0.841 & ZP1-7 + A1-5 \\
\hline$D+A$ & 7 & 0.400 & 0.673 & 0.863 & 0.187 & 0.847 & 0.820 & 0.754 & D1-2 + A1-5 \\
\hline$Z H+Z P+D$ & 14 & $\underline{0.783}$ & 0.839 & 0.827 & $\underline{0.775}$ & 0.891 & 0.920 & 0.823 & $\begin{array}{l}\text { ZH1-5 + ZP1-7 + } \\
\text { D1-2 }\end{array}$ \\
\hline $\mathrm{ZH}+\mathrm{ZP}+\mathbf{A}$ & 17 & 0.769 & $\underline{0.881}$ & 0.864 & 0.754 & 0.897 & 0.914 & $\underline{0.866}$ & $\begin{array}{l}\text { ZH1-5 + ZP1-7 + } \\
\text { A1-5 }\end{array}$ \\
\hline$Z P+D+A$ & 14 & 0.739 & 0.864 & $\underline{0.913}$ & 0.608 & $\underline{0.912}$ & $\underline{0.922}$ & 0.858 & $\begin{array}{l}\mathrm{ZH} 1-5+\mathrm{D} 1-2+ \\
\text { A1-5 }\end{array}$ \\
\hline $\begin{array}{l}\text { K-Světlé / } \\
\text { Tmavé }\end{array}$ & 7 & 0.580 & 0.658 & 0.743 & 0.227 & 0.813 & 0.698 & 0.165 & $\begin{array}{l}\text { ZH1 ZH4 ZP6 A1 } \\
\text { A3 A4 J1 }\end{array}$ \\
\hline $\begin{array}{l}\text { K-Tmavé / } \\
\text { Mohut. }\end{array}$ & 11 & 0.726 & 0.810 & 0.781 & $\underline{0.688}$ & 0.859 & 0.900 & $\underline{0.837}$ & $\begin{array}{l}\text { ZH1 ZH2 ZH3 } \\
\text { ZH4 ZH5 ZP1 ZP2 } \\
\text { ZP3 ZP4 ZP5 A2 }\end{array}$ \\
\hline $\begin{array}{l}\text { K - Přim. vib. } \\
\text { / Proved. }\end{array}$ & 13 & 0.667 & 0.783 & $\underline{0.895}$ & 0.621 & $\underline{0.907}$ & 0.896 & 0.772 & $\begin{array}{l}\text { ZP1 ZP2 ZP3 ZP4 } \\
\text { ZP6 ZP7 D1 D2 } \\
A 1 \text { A2 A3 A4 J1 }\end{array}$ \\
\hline $\begin{array}{l}\text { K-Světlé / } \\
\text { Pohybl. }\end{array}$ & 10 & 0.618 & 0.684 & 0.687 & 0.682 & 0.803 & 0.832 & 0.627 & $\begin{array}{l}\text { ZH2 ZH5 ZP2 ZP3 } \\
\text { ZP7 D1 A2 A3 } \\
\text { A5 J1 }\end{array}$ \\
\hline $\begin{array}{l}\text { K - Provede- } \\
\text { ni / Pohybl. }\end{array}$ & 12 & 0.735 & $\underline{0.811}$ & 0.825 & 0.680 & 0.862 & $\underline{0.903}$ & 0.765 & $\begin{array}{l}\text { ZH1 ZH2 ZH3 } \\
\text { ZH4 ZP1 ZP2 } \\
\text { ZP5 ZP6 ZP7 D1 } \\
\text { D2 A5 }\end{array}$ \\
\hline $\begin{array}{l}\text { K-Fa1 - Tma- } \\
\text { vé / Mohut. }\end{array}$ & 5 & 0.359 & 0.577 & 0.508 & 0.583 & 0.772 & 0.734 & 0.748 & $\begin{array}{l}\text { ZH1 ZH3 ZH4 } \\
\text { ZH5 ZP3 }\end{array}$ \\
\hline $\begin{array}{l}\text { K-Fa1 - Přim. } \\
\text { vib. / Proved. }\end{array}$ & 8 & 0.706 & 0.708 & 0.854 & 0.544 & 0.871 & 0.894 & 0.762 & $\begin{array}{l}\text { ZP1 ZP2 ZP4 ZP6 } \\
\text { ZP7 D1 D2 A2 }\end{array}$ \\
\hline $\begin{array}{l}\text { K-Fa1 - Svět- } \\
\text { lé / Proved. }\end{array}$ & 6 & $\underline{0.740}$ & 0.661 & 0.508 & 0.554 & 0.702 & 0.810 & 0.476 & $\begin{array}{l}\text { ZH2 ZP2 ZP4 ZP7 } \\
\text { D1 A5 }\end{array}$ \\
\hline $\begin{array}{l}\text { K-Fa1 - Přim. } \\
\text { vib. / Po- } \\
\text { hybl. }\end{array}$ & 6 & 0.584 & 0.649 & 0.806 & 0.403 & 0.847 & 0.858 & 0.593 & $\begin{array}{l}Z P 1 \text { ZP2 ZP6 ZP7 } \\
\text { D1 D2 }\end{array}$ \\
\hline $\begin{array}{l}\text { K-Fa1 - Svět- } \\
\text { lé / Pohybl. } \\
\end{array}$ & 7 & 0.541 & 0.506 & 0.498 & 0.425 & 0.715 & 0.746 & 0.107 & $\begin{array}{l}\text { ZH2 ZP2 ZP7 D1 } \\
\text { A3 A5 J1 }\end{array}$ \\
\hline $\begin{array}{l}\text { K-Fa2 - } \\
\text { Tmav. / } \\
\text { Mohut. }\end{array}$ & 6 & 0.676 & 0.644 & 0.673 & 0.188 & 0.783 & 0.861 & 0.648 & $\begin{array}{l}Z H 2 \text { ZP1 ZP2 ZP4 } \\
\text { ZP5 A2 }\end{array}$ \\
\hline
\end{tabular}

Tab. 8 Shoda hodnotitelů a rozdělení na skupiny dle hodnocení koloratury. 


\section{Souvislosti hodnocených vlastností}

V tabulce 9 jsou uvedeny vzájemné korelace jednotlivých vlastností, samostatně pro rondo (políčka jsou podbarvena bledě modře) a koloraturu. Šedá pole označují dvojice stejných vlastností, tak jak byly hodnoceny jednotlivými skupinami.

Vzájemné korelace hodnocení ronda s hodnoceními koloratury jsou uvedeny v tabulce 10. Šedé buňky označují shodné vlastnosti v obou testech. Nejvýznamnější korelace jsou znázorněny červeně, žlutou barvou jsou podbarvené buňky se vzájemnými vazbami mezi testy, které stojí za povšimnutí. 


\begin{tabular}{|c|c|c|c|c|c|c|c|c|c|}
\hline 플 & 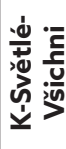 & 施 & 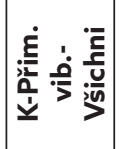 & 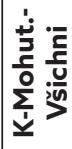 & 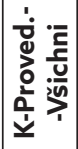 & 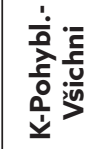 & 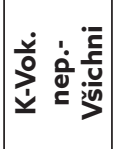 & 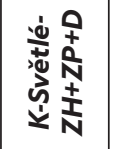 & \\
\hline 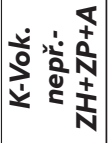 & & & & & & & 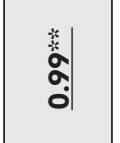 & & \\
\hline 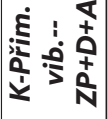 & 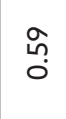 & & 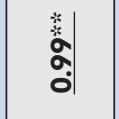 & & : & $\stackrel{\stackrel{*}{m}}{\stackrel{0}{o}}$ & & 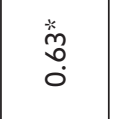 & \\
\hline 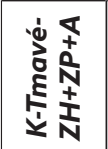 & 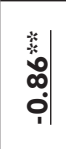 & $\begin{array}{l}\text { a. } \\
\text { वे. } \\
\text { वे. }\end{array}$ & & $\begin{array}{l}\text { : } \\
\vdots \\
0 \\
0 \\
0 \\
0\end{array}$ & & $\begin{array}{l}\text { Lnم } \\
\text { بْ }\end{array}$ & & 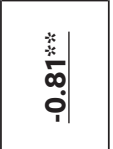 & \\
\hline 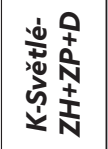 & $\begin{array}{l}\text { : } \\
\text { : } \\
\text { హ. } \\
0\end{array}$ & 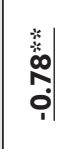 & $\begin{array}{l}\text { 米 } \\
\stackrel{0}{0}\end{array}$ & 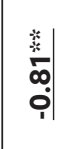 & 莫 & $\stackrel{\stackrel{*}{*}}{\stackrel{0}{0}}$ & & $\times$ & \\
\hline 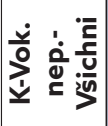 & & & & & & & $\times$ & 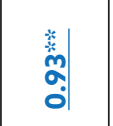 & 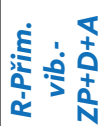 \\
\hline 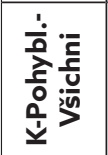 & 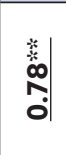 & $\begin{array}{l}\text { Lे } \\
\text { ơ }\end{array}$ & 章 & $\begin{array}{l}\text { 点 } \\
0 \\
0 \\
\end{array}$ & 荌 & $\times$ & $\begin{array}{l}\text { นึ? } \\
\text { ○े }\end{array}$ & $\begin{array}{l}\stackrel{*}{m} \\
\stackrel{0}{0}\end{array}$ & 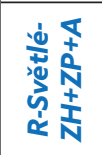 \\
\hline 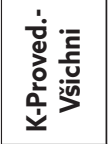 & $\stackrel{\stackrel{*}{n}}{\stackrel{*}{\circ}}$ & & 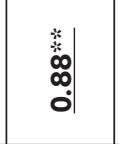 & $\begin{array}{l}\text { Nִ } \\
\text { ְִ }\end{array}$ & $\times$ & $\begin{array}{l}\text { 商 } \\
\text { ơ }\end{array}$ & $\begin{array}{l}. \\
\text { to } \\
0 \\
0 \\
0\end{array}$ & t. & 突 \\
\hline 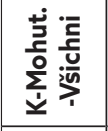 & 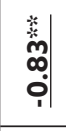 & $\begin{array}{c}\text { w. } \\
\text { o. } \\
\infty \\
0 \\
0\end{array}$ & $\begin{array}{l}\text { זn } \\
\text { in }\end{array}$ & $\times$ & 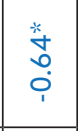 & 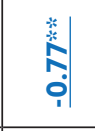 & $\begin{array}{l}\overline{0} \\
0\end{array}$ & $\begin{array}{l}\text { 炎 } \\
\text { o } \\
\end{array}$ & 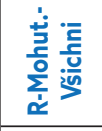 \\
\hline 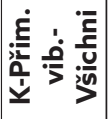 & 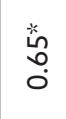 & & $\times$ & 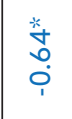 & 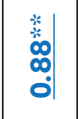 & $\begin{array}{l}\stackrel{0}{\leftrightarrow} \\
\stackrel{0}{0}\end{array}$ & 新 & 莣 & 安 \\
\hline \multirow[t]{3}{*}{ 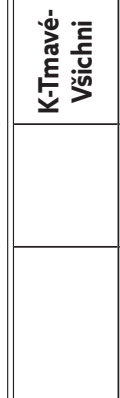 } & 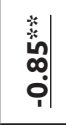 & $\times$ & & 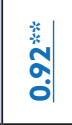 & $\begin{array}{l}\text { กิ } \\
\text { ְִ }\end{array}$ & 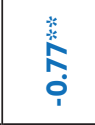 & & $\begin{array}{l}\text { Ln } \\
\text { ஸे } \\
\text { ị }\end{array}$ & 突空 \\
\hline & $\times$ & 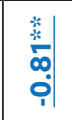 & స్ర & 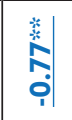 & 莫 & 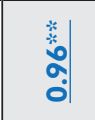 & $\begin{array}{l}\text { ஸे } \\
\text { ஸे }\end{array}$ & 贲 & 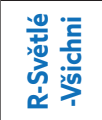 \\
\hline & & 童 & 泣 & 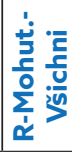 & 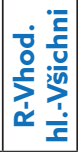 & 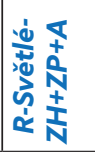 & 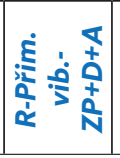 & 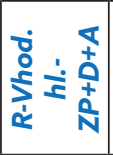 & 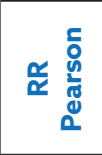 \\
\hline
\end{tabular}

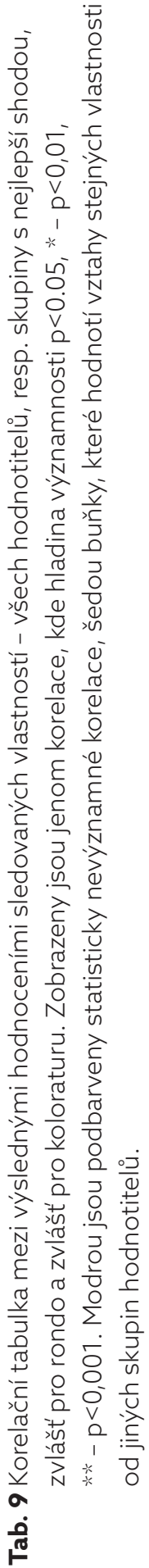




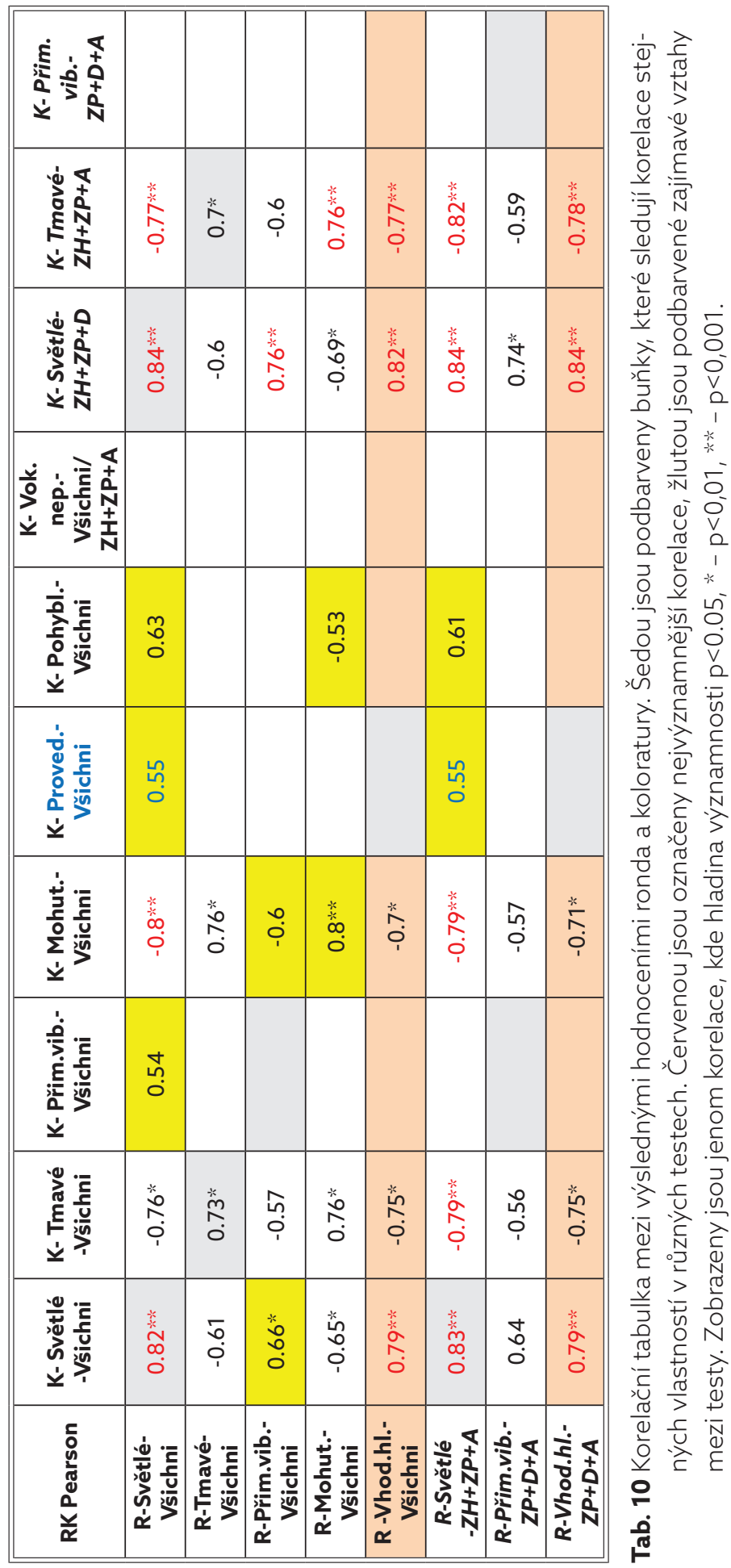


Tabulka 11 zobrazuje výsledky faktorové analýzy výsledných hodnocení ronda a koloratury pro skupinu všech hodnotitelů a pro skupiny s nejlepší shodou.

\begin{tabular}{|l|c|c|c|c|c|c|c|l||}
\hline Rondo & FA1 & FA2 & FA3 & & FA1 & FA2 & FA3 & Spec \\
\hline Světlé -Vš. & -0.54 & 0.38 & $-\mathbf{0 . 7 4}$ & & -0.50 & 0.35 & $-\mathbf{0 . 7 9}$ & Světlé -ZH+ZP+A \\
\hline Tmavé -Vš. & $\mathbf{0 . 9 1}$ & -0.18 & 0.36 & & $\mathbf{0 . 9 2}$ & -0.18 & 0.32 & Tmavé -Vš. \\
\hline Přim.vib.-Vš. & -0.28 & $\mathbf{0 . 9 3}$ & -0.12 & & -0.23 & $\mathbf{0 . 9 6}$ & -0.14 & Přim.vib.-ZP+D+A \\
\hline Mohutnost-Vš. & $\mathbf{0 . 8 9}$ & -0.41 & 0.18 & & $\mathbf{0 . 8 7}$ & -0.41 & 0.25 & Mohutnost-Vš. \\
\hline Vhod.hl.-Vš. & -0.25 & $\mathbf{0 . 8 7}$ & -0.36 & & -0.30 & $\mathbf{0 . 8 7}$ & -0.36 & Vhod.hl.-ZP+D+A \\
\hline \% & $\mathbf{7 5 . 7 9}$ & $\mathbf{9 2 . 0 9}$ & $\mathbf{9 7 . 1 6}$ & & $\mathbf{7 5 . 9 2}$ & $\mathbf{9 2 . 7 5}$ & $\mathbf{9 8 . 2 5}$ & \\
\hline Koloratura & $\mathbf{F A 1}$ & $\mathbf{F A 2}$ & $\mathbf{F A 3}$ & $\mathbf{F A 1}$ & $\mathbf{F A 2}$ & $\mathbf{F A 3}$ & $\mathbf{F A 4}$ & \\
\hline Světlé -Vš. & 0.55 & $\mathbf{- 0 . 8 0}$ & 0.01 & 0.40 & $-\mathbf{0 . 8 0}$ & -0.05 & 0.35 & Světlé -ZH+ZP+D \\
\hline Tmavé -Vš. & -0.16 & $\mathbf{0 . 9 5}$ & 0.16 & -0.21 & $\mathbf{0 . 9 3}$ & 0.21 & 0.04 & Tmavé -ZH+ZP+A \\
\hline Přim.vib.-Vš. & $\mathbf{0 . 8 8}$ & -0.20 & 0.02 & 0.61 & -0.19 & 0.03 & $\mathbf{0 . 7 5}$ & Přim.vib.-ZP+D+A \\
\hline Mohutnost-Vš. & -0.32 & $\mathbf{0 . 8 6}$ & 0.24 & -0.29 & $\mathbf{0 . 8 6}$ & 0.23 & -0.19 & Mohutnost-Vš. \\
\hline Provedení-Vš. & $\mathbf{0 . 9 6}$ & -0.24 & -0.05 & $\mathbf{0 . 8 9}$ & -0.26 & -0.01 & 0.34 & Provedení-Vš. \\
\hline Pohyblivost-Vš. & $\mathbf{0 . 8 7}$ & -0.43 & 0.03 & $\mathbf{0 . 8 8}$ & -0.43 & 0.05 & 0.13 & Pohyblivost-Vš. \\
\hline Vok.nep.-Vš. & $\mathbf{0 . 0 1}$ & $\mathbf{0 . 1 9}$ & $\mathbf{0 . 9 8}$ & 0.04 & 0.24 & $\mathbf{0 . 9 7}$ & 0.01 & Vok.nep.-ZH+ZP+A \\
\hline \% & $\mathbf{6 3 . 8 5}$ & $\mathbf{8 3 . 4 5}$ & $\mathbf{9 3 . 7 5}$ & $\mathbf{6 2 . 6 3}$ & $\mathbf{8 3 . 4 8}$ & $\mathbf{9 2 . 0 7}$ & $\mathbf{9 5 . 8 8}$ & \\
\hline
\end{tabular}

Tab. 11 Výsledky faktorové analýzy výsledných hodnocení ronda a koloratury pro skupinu všech hodnotitelů (v levé části) a skupiny s nejlepší shodou (pravá strana).

Vlastnosti slovního popisu

Nejčetnější vlastnosti užité $\mathrm{v}$ obou částech testů k popisu hodnocených vlastností jsou uvedeny v tabulce 12 (v tabulce jsou uvedeny celkové, absolutní a relativní četnosti a rozdíl četností mezi částmi koloratura a rondo).

\begin{tabular}{||l|c|c|c|c|c|c|}
\hline \multirow{2}{*}{ Vlastnost } & abs & \multicolumn{2}{|c|}{ Koloratura } & \multicolumn{2}{|c|}{ Rondo } & $\begin{array}{c}\text { Rozdíl \% } \\
\text { kol.- rond. }\end{array}$ \\
\cline { 2 - 6 } & sum & abs & \% z 462 & abs & \% z 480 & $\mathbf{1 2 . 5 5}$ \\
\hline \hline koloratura & 58 & 58 & 12.55 & 0 & 0.00 & $\mathbf{4 . 3 3}$ \\
\hline výška & 20 & 20 & 4.33 & 0 & 0.00 & $\mathbf{3 . 2 5}$ \\
\hline tón & 68 & 41 & 8.87 & 27 & 5.63 & $\mathbf{2 . 6 0}$ \\
\hline zvuk & 12 & 12 & 2.60 & 0 & 0.00 & $\mathbf{2 . 5 3}$ \\
\hline tempo & 47 & 29 & 6.28 & 18 & 3.75 & $\mathbf{- 2 . 0 8}$ \\
\hline dech & 10 & 0 & 0.00 & 10 & 2.08 & $\mathbf{- 2 . 3 4}$ \\
\hline barva & 52 & 20 & 4.33 & 32 & 6.67 & $\mathbf{- 2 . 7 1}$ \\
\hline výslovnost & 13 & 0 & 0.00 & 13 & 2.71 & $\mathbf{- 2 . 8 8}$ \\
\hline glissando & 22 & 4 & 0.87 & 18 & 3.75 & $\mathbf{- 3 . 3 3}$ \\
\hline frázování & 16 & 0 & 0.00 & 16 & 3.33 & $\mathbf{- 5 . 2 0}$ \\
\hline vibrato & 80 & 27 & 5.84 & 53 & 11.04 & $\mathbf{- 7 . 8 5}$ \\
\hline hlas & 211 & 85 & 18.40 & 126 & 26.25 & \\
\hline
\end{tabular}

Tab. 12 Četnosti nejčetnějších podstatných jmen užitých při popisu vlastností v obou částech testů a procentní rozdíl jejich relativních četností (K-R; koloratura-rondo). 
Nejčetnější přívlastky užité k popisu vlastností v obou částech testů jsou uvedeny v tabulce 13 (v tabulce jsou uvedeny celkové, absolutní a relativní četnosti a rozdíl četností mezi částmi koloratura a rondo).

\begin{tabular}{|l|c|c|c|c|c|c|}
\hline \multirow{2}{*}{ Vlastnost } & abs & \multicolumn{2}{|c|}{ Koloratura } & \multicolumn{2}{|c|}{ Rondo } & $\begin{array}{c}\text { Rozdíl \% } \\
\text { kol.- rond. }\end{array}$ \\
\cline { 2 - 6 } & sum & abs & $\% \mathbf{z ~ 8 3 5}$ & abs & \% z 1077 & $\mathbf{2 . 2 8}$ \\
\hline \hline pohyblivost & 19 & 19 & 2.28 & 0 & 0.00 & $\mathbf{2 . 0 4}$ \\
\hline přesnost & 17 & 17 & 2.04 & 0 & 0.00 & $\mathbf{1 . 9 2}$ \\
\hline těžkost & 16 & 16 & 1.92 & 0 & 0.00 & $\mathbf{1 . 8 8}$ \\
\hline lehkost & 92 & 49 & 5.87 & 43 & 3.99 & $\mathbf{1 . 8 0}$ \\
\hline těžkopádnost & 15 & 15 & 1.80 & 0 & 0.00 & $\mathbf{- 1 . 0 4}$ \\
\hline kulatost & 41 & 13 & 1.56 & 28 & 2.60 & $\mathbf{- 1 . 4 9}$ \\
\hline mohutnost & 16 & 0 & 0.00 & 16 & 1.49 & $\mathbf{- 1 . 5 8}$ \\
\hline měkkost & 17 & 0 & 0.00 & 17 & 1.58 & $\mathbf{- 1 . 6 7}$ \\
\hline jasnost & 18 & 0 & 0.00 & 18 & 1.67 & $\mathbf{- 1 . 8 6}$ \\
\hline dramatičnost & 20 & 0 & 0.00 & 20 & 1.86 & $\mathbf{- 2 . 1 9}$ \\
\hline světlost & 74 & 22 & 2.63 & 52 & 4.83 & \\
\hline
\end{tabular}

Tab. 13 Absolutní četnosti nejčetnějších přídavných jmen užitých při popisu vlastností v obou částech testů a procentní rozdíl jejich relativních četností (K-R; koloratura-rondo).

Počet respondentů, kteří použili určitý přívlastek, je uveden v tabulce 14. Tabulka je rozdělena na část se specifickými (četnější užívaní v konkrétní části árie) a nespecifickými (podobně četné) přívlastky.

\begin{tabular}{|c|c|c|c|c|}
\hline & \multicolumn{2}{|c|}{ Koloratura } & \multicolumn{2}{|c|}{ Rondo } \\
\hline & Vlastnost & $\mathrm{N}$ & Vlastnost & $\mathrm{N}$ \\
\hline \multirow{8}{*}{ 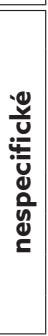 } & lehkost & 14 & lehkost & 12 \\
\hline & světlost & 11 & světlost & 15 \\
\hline & ostrost & 11 & ostrost & 12 \\
\hline & kulatost & 6 & kulatost & 11 \\
\hline & tmavost & 7 & tmavost & 9 \\
\hline & rychlost & 6 & rychlost & 6 \\
\hline & vyrovnanost & 6 & vyrovnanost & 6 \\
\hline & mohutnost & 5 & mohutnost & 7 \\
\hline \multirow{5}{*}{ 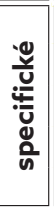 } & pohyblivost & 9 & dramatičnost & 8 \\
\hline & těžkost & 9 & vyváženost & 7 \\
\hline & přesnost & 7 & jasnost & 6 \\
\hline & těžkopádnost & 7 & výraznost & 6 \\
\hline & pomalost & 6 & srozumitelnost & 6 \\
\hline
\end{tabular}

Tab. 14 Shoda hodnotitelů v použivaných přivlastcích - počet hodnotitelů, který použivali uvedené př́vlastky. Jsou uvedeny jenom přívlastky, které používalo aspoň 6 hodnotitelů. 